\title{
A multi-proxy approach to determine Antarctic terrestrial palaeoclimate during the Late Cretaceous and Early Tertiary
}

\author{
Imogen Poole $\mathrm{a}^{\mathrm{a}, \mathrm{b}, *}$, David Cantrill ${ }^{\mathrm{c}}$, Torsten Utescher $^{\mathrm{d}}$ \\ ${ }^{a}$ Wood Anatomy Section, National Herbarium of the Netherlands, University of Utrecht Branch, P.O. Box 80102, \\ 3585 CS Utrecht, The Netherlands \\ ${ }^{\mathrm{b}}$ Palaeontological Museum, Oslo University, P.O. Box 1172 Blindern, N-0318 Oslo, Norway \\ ${ }^{\mathrm{c}}$ Swedish Museum of Natural History, Palaeobotany Section, Box 50007, Stockholm 104 05, Sweden \\ ${ }^{\mathrm{d}}$ Geologisches Institut, Rheinische Friedrich-Wilhelms-Universität, Nussallee 8, D-53115 Bonn, Germany
}

Received 29 March 2004; received in revised form 26 January 2005; accepted 11 March 2005

\begin{abstract}
Fossil wood is abundant throughout the Cretaceous and Tertiary sequences of the northern Antarctic Peninsula region. The fossil wood represents the remains of the vegetation that once grew at the southern high palaeolatitudes at $59-62^{\circ} \mathrm{S}$ through the general decline in climate, from the Late Cretaceous global warmth through to the mid-Eocene cool period prior to the onset of glaciation. This study draws on the largest dataset ever compiled of Antarctic conifer and angiosperm woods in order to derive clearer insights into the palaeoclimate. Parameters including mean annual temperature, mean annual range in temperature, cold month mean, warm month mean, mean annual precipitation are recorded. The fossil wood assemblages have been analysed using anatomical (physiognomic) characteristics to determine the palaeoclimate variables from the Coniacian-Campanian to the middle Eocene. These results are compared with data derived from Coexistence Analysis of the fossil floras (composed of leaves, wood and palynomorphs) and published data based on leaf physiognomic characters. These studies indicate a relatively warm and wet Late Cretaceous that becomes drier and cooler in the Early Paleocene and subsequently returns to warmer, wetter conditions by the latest Early Paleocene. During the Eocene the climate becomes relatively cool and dry once again. The discrepancies obtained from these two methods coupled with other published data are discussed in the context of the fluctuations in the temperatures of the surrounding oceans and global patterns of climate change.
\end{abstract}

(C) 2005 Elsevier B.V. All rights reserved.

Keywords: Palaeoclimate; Fossil; Wood; Nearest living relatives; Coexistence approach; Antarctica

* Corresponding author. Wood Anatomy Section, National Herbarium of the Netherlands, University of Utrecht Branch, P.O. Box 80102, 3585 CS Utrecht, The Netherlands.

E-mail address: i.poole@geo.uu.nl (I. Poole).

\section{Introduction}

Understanding the geological evolution of the Earth's climate and the controlling factors continue to challenge scientific thought - in particular the 
operation of Earth's climate system under greenhouse conditions and the effects of global warming in polarregions. In order to understand these changes a dataset with good spatial and temporal coverage is required, yet many areas of the globe remain poorly understood. This is true of the Antarctic where limited palaeoclimate data are available. Yet high latitude regions are areas of great importance for it is these regions where the amplitude of change is often at its greatest and thus easiest to detect in the geological record.

Fragmentation of the gondwanan landmass resulted in the creation of new oceanic basins that dramatically altered oceanic circulation patterns and with it the flux of heat around the globe. The progressive isolation of Antarctica into a polar position over the last 100 million years is generally accepted as being important in the evolution of the Earth's climate system (Kennett, 1977). Key events include the opening of oceanic gateways such as that between Australia (Tasmania) and Antarctica at 33.5 Ma. This isolation resulted in the development of the southern ocean and ultimately the creation of a polar water-mass. This event coincided with a major cooling resulting from oceanic and atmospheric isolation and the build up of ice on the Antarctic continent (Zachos et al., 2001). However, more recently modelling experiments have suggested that the effect of ocean gateways was relatively minor compared with forcing induced through declining carbon dioxide levels coupled with orbital forcing conditions (DeConto and Pollard, 2003). Although we have a better understanding of the interplay between different forcing mechanisms in determining climate states, we still cannot explain various perturbations in the oxygen and carbon isotope curves. Indeed it is becoming clear that regional responses to forcing processes vary considerably from the global average (Barrett, 2003).

A consequence of these findings is that we now require better spatial coverage of palaeoclimatic proxy data. Furthermore we need to better discriminate from where the signal contained in those proxies is originating, be it from deep bottom water, surface water or the atmosphere. Most proxy evidence of past climates relies on stable isotopes of marine organisms that record marine sea surface and bottom water temperatures but these proxies are associated with signal dampening and lag effects when used to retrodict terrestrial palaeoclimates (Poole et al., 2004). In recent years however, a variety of methods have been developed to estimate terrestrial climates (from oxygen isotope ratios of palaeosoil carbonates to plant physiognomy). Traditionally palaeoclimatic inferences based on plants have focused on growth characteristics and/or a 'bioclimatic' approach which relies on using taxonomically identifiable material under the assumption that the climatic requirements of the fossils are more or less similar to those of their 'nearest living relatives' (NLR) today (Kershaw and Nix, 1988; Mosbrugger, 1999). In order to quantify palaeoclimate data derived from the traditional bioclimatic-or NLR approach, Mosbrugger and Utescher (1997) devised the so-called Coexistance Approach (CA). This recent variation of the NLR approach has been applied to various Tertiary leaf floras (e.g. Pross et al., 1998; Utescher et al., 2000; Uhl et al., 2003; Liang et al., 2003). A number of techniques have also been devised whereby quantitative palaeoclimatic data can be derived from fossil plant material without relying so much on the taxonomic identity of the fossil under study. Fossil leaf assemblages have received the greater part of such attention whereby techniques exploit the known correlation between leaf physiognomy and climate parameters (e.g. Wolfe, 1971, 1979, 1993; Wilf, 1997; Wiemann et al., 1998a, 2001).

One type of plant material that has been little utilised in this respect is fossil wood. Yet wood is often widespread and abundant throughout geological time, and coupled with its robust nature, can yield a potentially rich archive of palaeoecological and palaeoclimate data (Poole and van Bergen, in press). Wheeler and Baas (1991) highlight the considerable potential for using features of dicot woods as an additional tool in the study of palaeoclimates. However this approach was only realised when a better understanding was gained into the relationship between qualitative and quantitative wood anatomical data from modern wood and prevailing climate (Wiemann et al., 1998b). Although still in its infancy such 'anatomical' approaches for deriving palaeoclimatic data have found that temperature-related climate variables, particularly mean annual temperature, yield good correlations with anatomy (Wiemann et al., 1999). In this paper we investigate the growth characteristics of fossil wood and compare the 
results of palaeoclimatic estimates based on wood anatomical characters with those derived from the CA for various Late Cretaceous to Paleogene wood floras from the Antarctic Peninsula. These results are then placed in context of palaeoclimatic reconstructions derived from other sources to further our understanding of climate change at southern high latitudes.

\section{Material and methods}

\subsection{Material}

A total of 600 conifer and angiosperm fossil wood specimens were used in this study. Most were collected by the authors (IP and DJC) from Alexander Island, Livingston Island, and islands within the James Ross Basin (Fig. 1). These were supplemented by the extensive wood collection housed at the British Antarctic Survey (BAS) and additional unpublished material from the collections housed at the Polish Academy of Science and the Swedish Museum of Natural History. The wood is petrified and mostly preserved in calcite although some samples originate from volcanogenic sediments and are thus silicified.

Fossil wood specimens were thin-sectioned using standard techniques (Haas and Rowe, 1999), and familial affinities determined as outlined in Poole et al. (2000). Any fossil that might have originated from root or small stem origin was eliminated from the dataset since determinations from such organs would potentially bias the results. Sectioned fossil specimens are deposited in the collections from which they were loaned.

Material spanning a stratigraphic range from the Late Cretaceous to the Middle Eocene was examined. Wood is unevenly distributed throughout the succession in Antarctica and sample coverage is poor during some time intervals (e.g. Cenomanian to Turonian). However, a number of key intervals contain sufficient

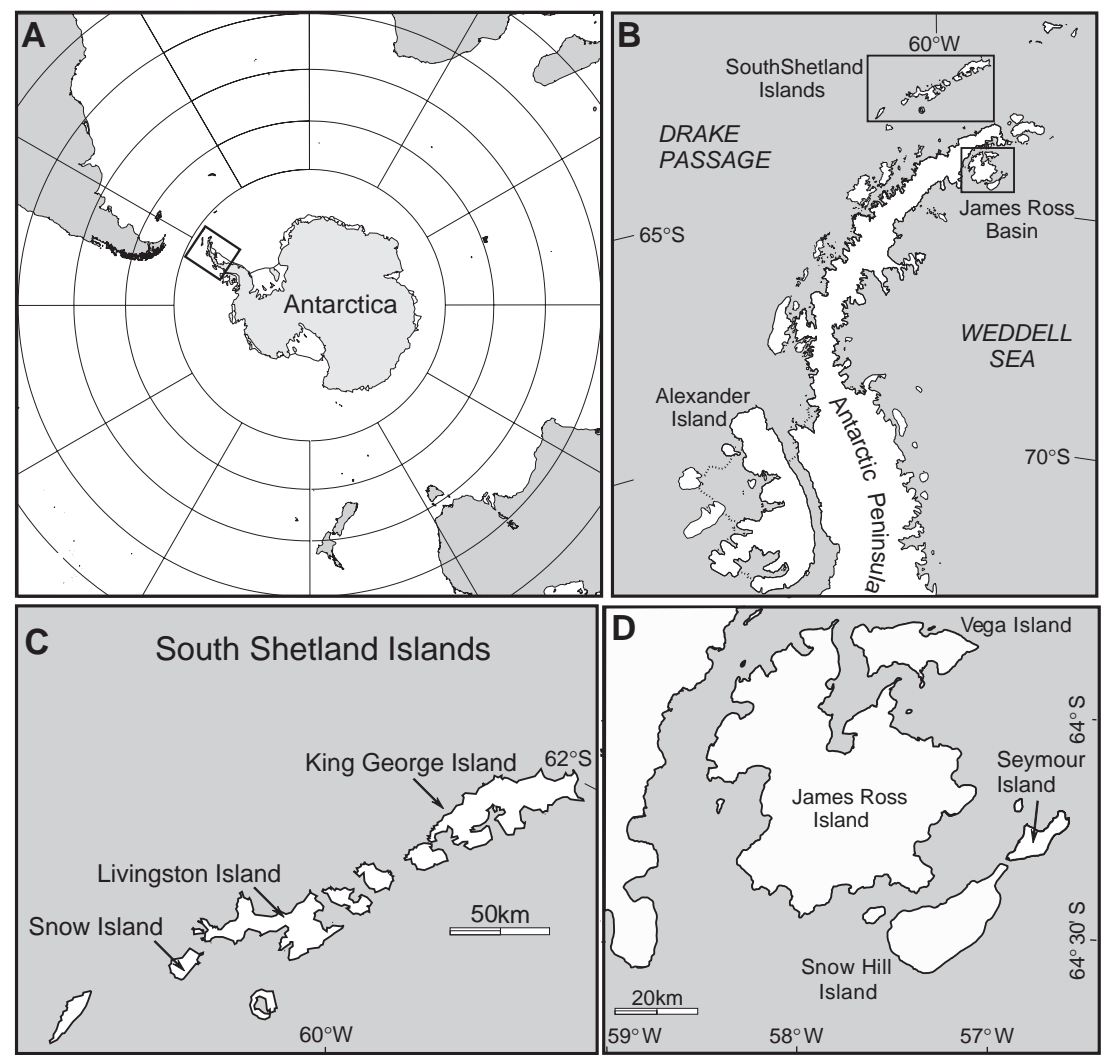

Fig. 1. Locality map showing key regions for fossil plants and geographic names mentioned in the text. 
sample coverage and taxonomic diversity to the meet statistical criteria (see below) required for analysis. Floras from the Coniacian (Williams Point Beds, plus additional material from the Larsen Basin), Santonian to Campanian (Santa Marta Formation, Snow Hill Island Formation), Late Maastrichtian (Lopez de Bertadano Formation), Early Paleocene (Lopez de Bertadano Formation, Sobral Formation), early Late Paleocene (Cross Valley Formation), late Early Eocene (La Meseta Formation, Telm 1-3), Middle to Late Eocene (La Meseta Formation, Telm 5-7), Middle Eocene (Fildes Formation) were included in the analysis.

\subsection{Methods}

For a comparison of wood anatomy and NLR approaches for quantitative palaeoclimate determinations, the multivariate anatomical analyses of Wiemann et al. (1998b, 1999) and the Coexistence Approach (Mosbrugger and Utescher, 1997) were employed. In addition other wood characters were studied to determine whether climatic signals could be determined from anatomical characters.

\subsubsection{Wood anatomy}

With an increased understanding of wood response to climate in recent years not all wood characters can be considered to be reliable palaeoclimate proxies (see Poole and van Bergen, in press and references therein for further details). Therefore anatomical studies were restricted to those characters that might provide general, non-quantitative climatic signals.

Due to overriding intrinsic biases associated with both taxonomic and ontogenetic status (Falcon-Lang, 2003, 2005, in press; Poole and van Bergen, in press) general conifer ring sequences were not analysed using mean sensitivity (cf. Francis and Poole, 2002). Instead characteristics of individual conifer taxa were traced through the stratigraphic succession in order to minimise possible taxonomic biases. Three genera were selected for analysis: Araucarioxylon, Podocarpoxylon and Phyllocladoxylon. These genera are abundant, represented by different organs (branch, twig and trunk wood) and have good stratigraphic coverage. Qualitative characteristics such as the percentage of false rings, indicating an interruption in growth due to unfavourable conditions, were examined to look for relative shifts in environmental indicators. The types of false rings can also give some indication of environmental conditions. Comparisons were made between trunk wood and branch woods as different parts of the plant differ in sensitivity to events (Chapman, 1994). For example, twigs and outer branches tend to start growing earlier in the season and so are more susceptible to spring frost damage than trunk wood.

In angiosperm wood material, growth ring characters can also provide additional general, albeit nonquantitative, climatic signals. Presence of false rings were studied to this end along with deferred optimum vessel diameter (DOVD; ring type 10 of Carlquist, 2001). DOVD indicates a commencement of growth at a time when soil moisture is available (due to rain or melting snow) but temperatures are probably below the required threshold such that peak transpiration is delayed until some weeks after initiation of wood production (Carlquist, 2001). This scenario is common to Nothofagus antarctica growing at ca. $55^{\circ} \mathrm{S}$ today. Finally, the type of porosity exhibited by fossil wood is expected to reflect the highly seasonal Antarctic environment if a similar correlation is assumed between climate in the past and present.

\subsubsection{Multivariate anatomical analysis}

The relationship between wood anatomical characters and climate was explored by Wiemann et al. (1998b, 1999) who developed models to determine climate from wood anatomy. For each of the intervals outlined above five climate variables namely mean annual temperature (MAT) mean annual range in temperature (MART) cold month mean temperature (CMMT), mean annual precipitation (MAP), and length of dry season (DRY) were determined from the fossil material using the regression equations of Wiemann et al. (1998b, Table 1 herein Eqs. (1)-(5); 1999, Table 1 herein Eqs. (9)-(16)). Since all angiosperm anatomical characters had evolved by the late Cretaceous (E. Wheeler, personal communication) we have not restricted the analysis (cf. Francis and Poole, 2002) but have used all the arcsine transformation formulae provided by Wiemann et al. (1999) for comparative purposes. However it should be noted that the results obtained for the material dated as Coniacian-Campanian may be less precise since the evolution of some anatomical characters 
cannot (yet) be confirmed from the fossil record (Wheeler and Baas, 1991; E. Wheeler, personal communication). However the results are included here for completeness.

The Vulnerability Index and Mesomorphy ratios of Carlquist (1977, Table 1) were also calculated since angiosperm xylem characters and available water in the habitat have been found to be positively correlated and might provide further insights into the relative degree of wetness of the Antarctic environment during the Late Cretaceous and Early Tertiary.

Francis and Poole (2002) undertook a similar study and their material has been included within this dataset. The total angiosperm dataset used herein represents an increase by $>60 \%$ when compared with that used by Francis and Poole (2002). It was hoped that the increased sample size, coupled with greater refinement for floral stratigraphic determination [as compared with the general epoch summary plots of Francis and Poole (2002)] would yield more precise palaeoclimate data at key intervals in the evolution of Antarctic ecology. Unfortunately the recommended sample size (i.e. 25 wood types from each locality for the floras used by Wiemann et al., 1998b), although greater than those given in Francis and Poole (2002), is still not considered ideal (Table 1) and thus standard errors for the variables are probably greater than those outlined by Wiemann et al. (1998b) although the degree of error is unknown (Wiemann, personal communication). Because this uncertainty exists, the data obtained from the fossil floras studied herein were plotted onto the original data set of Wiemann et al. (1999) to determine whether the individual anatomical characters reveal trends in MAT of Antarctica over this time. The caveats outlined by Wheeler and Baas (1991) when using fossil angiosperm wood to interpret ecology still apply. Moreover since the appearance of the angiosperms in the southern high latitudes and their subsequent radiation is coupled with the demise of the gymnosperms (and

Table 1

Climate variable formulae from Wiemann et al. [1998b (Eqs. (1)-(5)) and 1999] [arcsine transformation Eqs. (9)-(16) (note these relate to the equation numbers used by Wiemann et al., 1999] and Carlquist (1977) with the calculated climate variable for each flora given

\begin{tabular}{|c|c|c|c|c|c|c|c|c|}
\hline \multicolumn{3}{|c|}{ Equation } & \multirow{2}{*}{$\frac{\mathrm{ME}}{10}$} & \multirow{2}{*}{$\frac{\mathrm{EE}}{6}$} & \multirow{2}{*}{$\frac{1 \mathrm{EP}}{4}$} & \multirow{2}{*}{$\frac{\mathrm{EP}}{9}$} & \multirow{2}{*}{$\frac{\mathrm{LM}}{11}$} & \multirow{2}{*}{$\frac{\mathrm{C}-\mathrm{C}}{8}$} \\
\hline & $n$ & (sample size in number of taxa) & & & & & & \\
\hline (1) & MAT $=$ & $\begin{array}{l}13.40-0.250(\text { spir })+0.637(>10 \text { ser })+0.255(\text { het } 4+)+ \\
0.416 \text { (stor })-0.213(\mathrm{abs})\end{array}$ & 8.7 & 8.0 & 11.4 & 6.6 & 3.4 & 19.3 \\
\hline (2) & MART $=$ & $\begin{array}{l}4.16+0.319 \text { (spir) }+0.135(<100 \mu \mathrm{m})- \\
0.373(>10 \text { ser })-0.154(\text { het } 4+)\end{array}$ & 10.7 & 11.7 & 8.2 & 9.5 & 9.7 & 3.4 \\
\hline (3) & $\mathrm{CMMT}=$ & $\begin{array}{l}9.91-0.355 \text { (spir) }-0.098(<100 \mu \mathrm{m})+0.845(>10 \text { ser })+ \\
0.368(\text { het } 4+)+0.528 \text { (stor })-0.210(\text { abs })\end{array}$ & 11.6 & 7.1 & 10.3 & 10.4 & 8.2 & 29.0 \\
\hline (4) & $\mathrm{MAP}=$ & $-6.06+6.332(\mathrm{sept})+7.901(\mathrm{abs})$ & 3710 & 3890 & 2560 & 4230 & 4940 & 5620 \\
\hline (5) & $\mathrm{DRY}=$ & $6.18-0.186($ mult $)-0.122($ sept $)$ & -10.5 & -5.4 & -9.0 & -6.5 & -7.9 & -10.7 \\
\hline (9) & MAT $=$ & $-4.30+34.14($ para $)$ & 12.0 & 10.4 & 17.3 & 9.3 & 10.0 & 8.8 \\
\hline (10) & $\mathrm{MAT}=$ & $21.70+38.23$ (stor) -20.29 & 16.7 & 16.3 & 17.1 & 17.3 & 21.7 & 21.7 \\
\hline (11) & MAT $=$ & $27.82-15.16(<100$ um $)+24.17$ (stor) & 12.6 & 13.7 & 16.7 & 14.5 & 16.4 & 11.2 \\
\hline (12) & MAT $=$ & $24.78+36.57$ (stor) $-15.61(\mathrm{marg})-16.41(\mathrm{abs})$ & 8.8 & 10.0 & 12.7 & 8.1 & 10.8 & 9.8 \\
\hline (13) & MAT $=$ & $14.80-16.89$ (homo) +24.86 (stor) +14.92 (para) & 14.9 & 11.5 & 16.4 & 10.5 & 12.1 & 16.0 \\
\hline (14) & MAT $=$ & $30.47-19.39$ (homo) +35.35 (stor) $-19.27(\mathrm{abs})$ & 8.2 & 6.7 & 11.4 & 3.1 & 3.7 & 7.7 \\
\hline (15) & MAT $=$ & $17.07+25.23$ (stor) $-23.17(\mathrm{abs})+13.79(\mathrm{sept})$ & 2.3 & 6.0 & 9.4 & 0.3 & 1.4 & 0.6 \\
\hline (16) & MAT $=$ & $\begin{array}{l}6.25+27.15 \text { (mult) }-15.72 \text { (spir) } \\
-21.83(<100 \mu \mathrm{m})+16.88(\mathrm{RP})+33.43 \text { (para) }\end{array}$ & 38.9 & 26.3 & 44.9 & 31.6 & 33.2 & 27.5 \\
\hline & $\mathrm{VI}=$ & mean vessel diameter/no. $\mathrm{mm}^{-2}$ & 0.85 & 0.55 & 0.59 & 0.62 & 0.83 & 1.98 \\
\hline & $\mathrm{MR}=$ & $\begin{array}{l}\text { (mean vessel diameter/no. vessels per } \mathrm{mm}^{-2} \text { ) } \\
\mathrm{x} \text { vessel element length }\end{array}$ & 552 & 292 & 321 & 341 & 389 & 1332 \\
\hline
\end{tabular}

MAT, mean annual temperature; MART, mean annual range in temperature; CMMT, cold month mean temperature; MAP, mean annual precipitation; DRY, length of dry season in months; MAT, mean annual temperature; ME, middle Eocene; EE, Early Eocene; lEP, latest Early Paleocene; EP, Early Paleocene; LM, Late Maastrichtian; C-C, Coniacian-Campanian; spir, vessels with spiral thickenings; stor, rays storied; abs, axial parenchyma rare or absent; $<100 \mu \mathrm{m}$, vessel diameter less than $100 \mu \mathrm{m}$; >10ser, rays commonly more than 10 seriate; het4+, rays heterocellular with 4 or more rows of upright cells; sept, septate fibres; mult, vessels with multiple perforations; para, paratracheal parenchyma; marg, marginal parenchyma present; homo, homocellular rays; RP, wood ring-porous; VI, Vulnerability Index; MR, Mesomorphy Ratio. 
Table 2

Taxa used in the Coexistence Analysis approach with morphotaxa names and nearest living relatives provided where possible

\begin{tabular}{|c|c|c|c|c|}
\hline Family & Morphotaxa & Nearest living relative & Organ & Reference \\
\hline \multicolumn{5}{|c|}{ Middle Eocene (King George Island) } \\
\hline Araucariaceae & & Araucaria sect Eutacta & leaf & Hunt, 2001 \\
\hline Cupressaceae & Cupressinoxylon & Libocedrus & leaf, wood & Hunt, 2001; Poole et al., 2001 \\
\hline \multirow[t]{2}{*}{ Podocarpaceae } & Podocarpoxylon & Podocarpus & leaf, wood & Hunt, 2001; Poole et al., 2001 \\
\hline & & Acmopyle & leaf & Hunt, 2001 \\
\hline Atherospermataceae & Laurelites jamesrossii & Laureliopsis philippiana & wood & Cantrill and Poole, 2004 \\
\hline \multirow[t]{5}{*}{ Cunoniaceae } & Caldcluvioxylon collinsensis & Ackama & wood & Cantrill and Poole, 2004 \\
\hline & Weinmannioxylon & Weinmannia & wood & Cantrill and Poole, 2004 \\
\hline & nordenskjoeldii & Weinmannia & leaf & Hunt, 2001 \\
\hline & & Ceratopetalum & leaf & Hunt, 2001 \\
\hline & & Anodopetalum & leaf & Hunt, 2001 \\
\hline \multirow[t]{3}{*}{ Eucryphiaceae } & Eucryphiaceoxylon fildense & Eucryphia & wood & Cantrill and Poole, 2004 \\
\hline & & Eucryphia moorei & leaf & Hunt, 2001 \\
\hline & & Eucryphia glutinosa & leaf & Hunt, 2001 \\
\hline Myrtaceae & Myceugenelloxylon antarcticus & Luma & wood & Cantrill and Poole, 2004 \\
\hline \multirow[t]{7}{*}{ Nothofagaceae } & Nothofagoxylon scalariforme & Nothofagus antarctica & wood & Cantrill and Poole, 2004 \\
\hline & & Nothofagus antarctica & leaf & Hunt, 2001 \\
\hline & & Nothofagus pumilio & leaf & Hunt, 2001 \\
\hline & & Nothofagus gunnii & leaf & Hunt, 2001 \\
\hline & Nothofagoxylon palaeoalessandri & Nothofgaus cunninghamii & wood & Cantrill and Poole, 2004 \\
\hline & Nothofagoxylon corrugatus & Nothofagus solandrii & wood & Cantrill and Poole, 2004 \\
\hline & Nothofagoxylon ruei & Nothofagus alpina & wood & Cantrill and Poole, 2004 \\
\hline \multirow[t]{6}{*}{ Proteaceae } & & Gevuina-Hicksbeachia & pollen & Dettmann and Jarzen, 1991 \\
\hline & & Adenanthos barbigera & pollen & Dettmann and Jarzen, 1991 \\
\hline & & Carnarvonia & pollen & Dettmann and Jarzen, 1991 \\
\hline & & Telopea truncata & pollen & Dettmann and Jarzen, 1991 \\
\hline & & Beauprea elegans & pollen & Dettmann and Jarzen, 1991 \\
\hline & & Knightia excelsa & leaf & Hunt, 2001 \\
\hline Rubiaceae & Dicotyloxylon pluriperforatum & Coprosma & wood & Torres, 1990 \\
\hline Sterculiaceae & Dicotyophyllum washbernii & Brachychiton populneus & leaf & Hunt, 2001 \\
\hline \multicolumn{5}{|l|}{ Lower Middle Eocene } \\
\hline Cycadales & Cyacadopites & & & \\
\hline \multirow[t]{2}{*}{ Araucariaceae } & Araucarioxylon & Araucaria & wood & Cantrill and Poole, 2004 \\
\hline & Araucariacites australis & Araucaria & pollen & Greenhalgh, 2002 \\
\hline Cupressaceae & Cupressinoxylon & Libocedrus & wood & Torres et al., 1994 \\
\hline \multirow[t]{7}{*}{ Podocarpaceae } & Podocarpoxylon & Podocarpus & wood & Cantrill and Poole, 2004 \\
\hline & Phyllocaldoxylon & Phyllocladus & wood & Cantrill and Poole, 2004 \\
\hline & Dacrydiumites florinii & & pollen & Greenhalgh, 2002 \\
\hline & Phyllocladites mawsonii & $\begin{array}{l}\text { Phyllocladus, } \\
\text { Lagarostrobus }\end{array}$ & pollen & Greenhalgh, 2002 \\
\hline & Podocarpidites & Podocarpus & pollen & Greenhalgh, 2002 \\
\hline & Podocarpus dacryidioides & Dacrydium dacryidioides & pollen & Greenhalgh, 2002 \\
\hline & Microcachyridites antarcticus & Microcachrys & pollen & Greenhalgh, 2002 \\
\hline ?Arecaceae & Gemmamonocolpites & & pollen & Askin, 1997 \\
\hline Atherospermataceae & Atherospermoxylon & Daphnandra & wood & Cantrill and Poole, 2004 \\
\hline Aquifoliaceae & Ilexpollenites & Ilex & pollen & Askin, 1997 \\
\hline Casuarinaceae & Haloragacidites harrisii & Casurina & pollen & Askin, 1997 \\
\hline Cunoniaceae & $\begin{array}{l}\text { Weinmannioxylon } \\
\text { nordenskjoeldii }\end{array}$ & Weinmannia & wood & Cantrill and Poole, 2004 \\
\hline Cunoniaceae/Elaeocarpaceae & Tricolporites & & pollen & Askin, 1997 \\
\hline Droseraceae & Fischeripollis, Droseridites & & pollen & Askin, 1997 \\
\hline Epacridaceae/Ericaceae & Ericipites scabratus & & pollen & Askin, 1997 \\
\hline
\end{tabular}


Table 2 (continued)

\begin{tabular}{|c|c|c|c|c|}
\hline Family & Morphotaxa & Nearest living relative & Organ & Reference \\
\hline \multicolumn{5}{|l|}{ Lower Middle Eocene } \\
\hline Eucryphiaceae & Eucryphiaceoxylon eucryphioides & Eucryphia & wood & Cantrill and Poole, 2004 \\
\hline Euphorbiaceae & Malvacipollis subtilis & & pollen & Askin, 1997 \\
\hline Gunneraceae & Tricolpites reticulates & Gunnera & pollen & Askin, 1997 \\
\hline Liliaceae & Liliacidites & & pollen & Askin, 1997 \\
\hline Myrtaceae & Myrtaceidites & & pollen & Askin, 1997 \\
\hline \multirow[t]{3}{*}{ Nothofagaceae } & Nothofagoxylon ruei & Nothofagus alpina & wood & Cantrill and Poole, 2004 \\
\hline & Nothofagoxylon scalariforme & Nothofagus antarctica & wood & Cantrill and Poole, 2004 \\
\hline & Nothofagoxylon corrugatus & Nothofagus solandrii & wood & Cantrill and Poole, 2004 \\
\hline Olacaceae & Anacolosidites & & pollen & Askin, 1997 \\
\hline \multirow{7}{*}{ Proteaceae } & & Gevuina-Hicksbeachia & pollen & Dettmann and Jarzen, 1991 \\
\hline & & Adenanthos barbigera & pollen & Dettmann and Jarzen, 1991 \\
\hline & & Carnarvonia & pollen & Dettmann and Jarzen, 1991 \\
\hline & & Telopea truncata & pollen & Dettmann and Jarzen, 1991 \\
\hline & & Beauprea elegans & pollen & Dettmann and Jarzen, 1991 \\
\hline & Banksieaeidites & Banksia & pollen & Askin, 1997 \\
\hline & Granodiporites & & pollen & Askin, 1997 \\
\hline Restionaceae & Milfordia & & pollen & Askin, 1997 \\
\hline Sapindaceae-Cupanieae & Cupanieidites orthoteichus & & pollen & Askin, 1997 \\
\hline Trimeniaceae & Periporopollenites polyoratus & & pollen & Askin, 1997 \\
\hline \multicolumn{5}{|c|}{ Early-Late Palaeocene (James Ross Basin) } \\
\hline \multirow[t]{3}{*}{ Proteaceae } & & Gevuina-Hicksbeachia & pollen & Dettmann and Jarzen, 1991 \\
\hline & & Adenanthos barbigera & pollen & Dettmann and Jarzen, 1991 \\
\hline & & Beauprea elegans & pollen & Dettmann and Jarzen, 1991 \\
\hline Atherospermataceae & Atherospermoxylon & Daphnandra & wood & Cantrill and Poole, 2004 \\
\hline \multirow{3}{*}{ Nothofagaceae } & Nothofagoxylon scalariforme & Nothofagus antarctica & wood & Cantrill and Poole, 2004 \\
\hline & Nothofagoxylon ruei & Nothofagus alpina & wood & Cantrill and Poole, 2004 \\
\hline & Nothofagoxylon corrugatus & Nothofagus solandrii & wood & Cantrill and Poole, 2004 \\
\hline \multicolumn{5}{|c|}{ Mid Early Palaeocene (James Ross Basin) } \\
\hline Araucariaceae & Araucarioxylon & Araucaria & wood & Cantrill and Poole, 2004 \\
\hline Phyllocladaceae & Phyllocladoxylon & Dacryidium, & wood & Cantrill and Poole, 2004 \\
\hline \multirow[t]{6}{*}{ Podocarpaceae } & Podocarpoxylon & Podocarpus & wood & Cantrill and Poole, 2004 \\
\hline & Phyllocladites mawsonii & $\begin{array}{l}\text { Phyllocladus, } \\
\text { Lagarostrobus }\end{array}$ & pollen & Greenhalgh, 2002 \\
\hline & Dacrydiumites florinii & Dacrydium & pollen & Greenhalgh, 2002 \\
\hline & Microcachyridites antarcticus & Microcachyrs & pollen & Greenhalgh, 2002 \\
\hline & Podocarpus dacryidioides & Dacrydium dacrydioides & pollen & Greenhalgh, 2002 \\
\hline & Cycadopites & & pollen & Greenhalgh, 2002 \\
\hline Atherospermataceae & Laurelites jamesrossii & Laureliopsis philippiana & wood & Cantrill and Poole, 2004 \\
\hline Eucryphiaceae & Eucryphiaceoxylon eucryphioides & Eucryphia & wood & Cantrill and Poole, 2004 \\
\hline Illiciaceae & Illicioxylon & Illicium & wood & Cantrill and Poole, 2004 \\
\hline \multirow[t]{6}{*}{ Nothofagaceae } & Nothofagoxylon kraeuseli & Nothofagus cunninghamii & wood & Cantrill and Poole, 2004 \\
\hline & Nothofagoxylon scalariforme & Nothofagus antarctica & wood & Cantrill and Poole, 2004 \\
\hline & Myceugenelloxylon antarcticus & Luma & wood & Cantrill and Poole, 2004 \\
\hline & Nothofagoxylon ruei & Nothofagus alpina & wood & Cantrill and Poole, 2004 \\
\hline & Nothofagoxylon corrugatus & Nothofagus solandrii & wood & Cantrill and Poole, 2004 \\
\hline & Nothofagoxylon triseriatum & Nothofagus glauca & wood & Cantrill and Poole, 2004 \\
\hline \multirow[t]{4}{*}{ Proteaceae } & & Gevuina-Hicksbeachia & pollen & Dettmann and Jarzen, 1991 \\
\hline & & Adenanthos barbigera & pollen & Dettmann and Jarzen, 1991 \\
\hline & Peninsulapollis gillii & & pollen & Greenhalgh, 2002 \\
\hline & Peninsulapollis truswelli & & pollen & Greenhalgh, 2002 \\
\hline
\end{tabular}


Table 2 (continued)

\begin{tabular}{|c|c|c|c|c|}
\hline Family & Morphotaxa & Nearest living relative & Organ & Reference \\
\hline \multicolumn{5}{|c|}{ Mid Early Palaeocene (James Ross Basin) } \\
\hline \multirow[t]{2}{*}{ Proteaceae } & Beaupreadites verrucosus & & pollen & Greenhalgh, 2002 \\
\hline & Propylipollis sp. & & pollen & Greenhalgh, 2002 \\
\hline \multirow[t]{2}{*}{ Gunneraceae } & Tricolpites & Gunnera & pollen & Greenhalgh, 2002 \\
\hline & Clavamonocolpites polygonalis & & pollen & Greenhalgh, 2002 \\
\hline \multirow[t]{3}{*}{ Lilliaceae, Iridiaceae } & Liliacidites sp. & & pollen & Greenhalgh, 2002 \\
\hline & Liliacidites variegatus & & pollen & Greenhalgh, 2002 \\
\hline & Liliacidites kaitangataensis & & pollen & Greenhalgh, 2002 \\
\hline ?Arecaceae & Gemmamonocolpites pilulus & & pollen & Greenhalgh, 2002 \\
\hline ?Palmae & Arecipites sp. & & pollen & Greenhalgh, 2002 \\
\hline \multicolumn{5}{|c|}{ Late Maastrichtian (James Ross Basin) } \\
\hline \multirow[t]{2}{*}{ Araucariaceae } & Araucarioxylon & Araucaria & $\begin{array}{l}\text { wood and } \\
\text { pollen }\end{array}$ & $\begin{array}{l}\text { Cantrill and Poole, 2004; } \\
\text { Dettmann and Thomson, } 1987\end{array}$ \\
\hline & Araucariacites australis & Araucaria & pollen & Partridge, 2002 \\
\hline \multirow[t]{2}{*}{ Phyllocladaceae } & Phyllocladoxylon & Dacrydium & wood & Cantrill and Poole, 2004 \\
\hline & & Phyllocladus & wood & Cantrill and Poole, 2004 \\
\hline \multirow[t]{8}{*}{ Podocarpaceae } & Podocarpoxylon & Podocarpus & wood & Cantrill and Poole, 2004 \\
\hline & & Dacrydium & pollen & Dettmann and Thomson, 1987 \\
\hline & & Microcachrys & pollen & Dettmann and Thomson, 1987 \\
\hline & & Lagarostrobus & pollen & Dettmann and Thomson, 1987 \\
\hline & Phyllocladiites mawsonii & $\begin{array}{l}\text { Phyllocladus, } \\
\text { Lagarostrobus }\end{array}$ & pollen & Partridge, 2002 \\
\hline & Dacrydiumites florinii & Dacrydium & pollen & Partridge, 2002 \\
\hline & Podocarpidites sp. & Podocarpus & pollen & Partridge, 2002 \\
\hline & Micrcachyridites & Microcachrys & pollen & Partridge, 2002 \\
\hline Cycadales & Cycadopites & Cycadales & pollen & Partridge, 2002 \\
\hline \multirow[t]{2}{*}{ Atherospermataceae } & Laurelites jamesrossii & Laureliopsis philippiana & wood & Cantrill and Poole, 2004 \\
\hline & Atherospermoxylon & Daphnandra & wood & Cantrill and Poole, 2004 \\
\hline \multirow[t]{2}{*}{ Aquifoliaceae } & & Ilex & pollen & Dettmann, 1989 \\
\hline & Illexpollenites sp. & & pollen & Partridge, 2002 \\
\hline Bombacaceae & Bombacacidites bombaxoides & & pollen & Askin, 1989 \\
\hline \multirow[t]{3}{*}{ Gunneraceae } & & Gunnera & pollen & Dettmann, 1989 \\
\hline & Tricolpites waiparaensis & & pollen & Partridge, 2002 \\
\hline & Tricolpites confessus & & pollen & Partridge, 2002 \\
\hline Illiciaceae & Illicioxylon & Illicium & wood & Cantrill and Poole, 2004 \\
\hline Lauraceaea & Sassafrasoxylon & Sassafras & wood & Cantrill and Poole, 2004 \\
\hline \multirow[t]{2}{*}{ Myrtaceae } & Myceugenelloxylon antarcticus & Luma & wood & Cantrill and Poole, 2004 \\
\hline & & - & pollen & Dettmann, 1989 \\
\hline \multirow[t]{6}{*}{ Nothofagaceae } & Nothofagoxylon scalariforme & Nothofagus antarctica & wood & Cantrill and Poole, 2004 \\
\hline & Nothofagoxylon corrugatus & Nothofagus solandrii & wood & Cantrill and Poole, 2004 \\
\hline & Nothofagoxylon aconcaguaense & Nothofagus obliqua & wood & Cantrill and Poole, 2004 \\
\hline & Nothofagoxylon ruei & Nothofagus alpina & wood & Cantrill and Poole, 2004 \\
\hline & Nothofagoxylon scalariforme & Nothofagus antarctica & wood & Cantrill and Poole, 2004 \\
\hline & Nothofagoxylon kraeuseli & Nothofagus cunninghamii & wood & Cantrill and Poole, 2004 \\
\hline Olacaceae & Anacolosidites sectus & & pollen & Askin, 1989 \\
\hline \multirow[t]{8}{*}{ Proteaceae } & & Gevuina-Hicksbeachia & pollen & Dettmann and Jarzen, 1991 \\
\hline & & Adenanthos barbigera & pollen & Dettmann and Jarzen, 1991 \\
\hline & & Knightia & pollen & Dettmann and Jarzen, 1991 \\
\hline & & Stirlingia tenuifolia & pollen & Dettmann and Jarzen, 1991 \\
\hline & & Grevillea & pollen & Dettmann and Jarzen, 1991 \\
\hline & & Telopea truncata & pollen & Dettmann and Jarzen, 1991 \\
\hline & & Beauprea elegans & pollen & Dettmann and Jarzen, 1991 \\
\hline & & Persoonia lanceolata & pollen & Dettmann and Jarzen, 1991 \\
\hline
\end{tabular}


Table 2 (continued)

\begin{tabular}{|c|c|c|c|c|}
\hline Family & Morphotaxa & Nearest living relative & Organ & Reference \\
\hline \multicolumn{5}{|c|}{ Late Maastrichtian (James Ross Basin) } \\
\hline \multirow[t]{16}{*}{ Proteaceae } & & Adenanthos barbigera & pollen & Dettmann and Jarzen, 1991 \\
\hline & & Beauprea & pollen & $\begin{array}{l}\text { Dettmann and Thomson, } \\
\text { 1987; Dettmann, } 1989\end{array}$ \\
\hline & & Macadamia & pollen & Dettmann, 1989 \\
\hline & & Gevuina/Hicksbeachia & pollen & $\begin{array}{l}\text { Dettmann, 1989; Dettmann } \\
\text { and Jarzen, } 1991\end{array}$ \\
\hline & & Knightia & pollen & Dettmann and Jarzen, 1991 \\
\hline & & Stirlingia tenuifolia & pollen & Dettmann and Jarzen, 1991 \\
\hline & & Xylomelum & pollen & Dettmann, 1989 \\
\hline & & Grevillea & pollen & Dettmann and Jarzen, 1991 \\
\hline & & Carnarvonia & pollen & Dettmann and Jarzen, 1991 \\
\hline & & Telopea truncata & pollen & Dettmann and Jarzen, 1991 \\
\hline & Peninsulapollis askinae & & pollen & Partridge, 2002 \\
\hline & Peninsulapollis gillii & & pollen & Partridge, 2002 \\
\hline & Proteacidites spp. & & pollen & Partridge, 2002 \\
\hline & Cranwellipollis palisadus & & pollen & Partridge, 2002 \\
\hline & Cranwellia cf striatus & & pollen & Partridge, 2002 \\
\hline & Beaupreaidites sp. & & pollen & Partridge, 2002 \\
\hline Sapindaceae-Cupanieae & Cupaniedites orthoteichus & & pollen & Askin, 1989 \\
\hline \multirow[t]{2}{*}{ Chloranthaceae } & Clavamonocolpites polygonalis & & pollen & Askin, 1992 \\
\hline & Clavatipollenites hughesi & & pollen & Askin, 1992 \\
\hline Myrtaceae & Myrtaceidites sp. & & pollen & Partridge, 2002 \\
\hline Lilliaceae, Iridiaceae & Liliacidites spp. & & pollen & Partridge, 2002; Askin, 1992 \\
\hline \multirow[t]{9}{*}{ ?Palmae } & Gemmamonocolpites pilulus & & pollen & Askin, 1992 \\
\hline & Arecipites & & pollen & Partridge, 2002 \\
\hline & & & pollen & Partridge, 2002 \\
\hline & Stellidiopollis annulatus & & pollen & Partridge, 2002 \\
\hline & Triporopoellenites spp. & & pollen & Partridge, 2002 \\
\hline & Ericipites sp. & & pollen & Partridge, 2002 \\
\hline & Retistephanocolporites sp. A & & pollen & Partridge, 2002 \\
\hline & Polycolpites cf langstonii & & pollen & Partridge, 2002 \\
\hline & Ailanthipites sp. & & pollen & Partridge, 2002 \\
\hline \multicolumn{5}{|c|}{ Coniacian to Campanian (James Ross Basin) } \\
\hline Araucariaceae & Araucariopitys & Araucaria & $\begin{array}{l}\text { wood, } \\
\text { pollen }\end{array}$ & $\begin{array}{l}\text { Cantrill and Poole, 2004; } \\
\text { Dettmann and Thomson, } 1987\end{array}$ \\
\hline \multirow[t]{3}{*}{ Podocarpcaceae } & Podocarpoxylon & Podocarpus & wood & Cantrill and Poole, 2004 \\
\hline & & Microcachrys & pollen & Dettmann and Thomson, 1987 \\
\hline & & Dacrydium & pollen & Dettmann, 1989 \\
\hline Cycadales & Centricycas & $\begin{array}{l}\text { Lepidozamia, } \\
\text { Macrozamia, } \\
\text { Encephalartos }\end{array}$ & stem & Cantrill, 2000 \\
\hline \multirow[t]{2}{*}{ Atherospermataceae } & Atherospermoxylon & Daphnandra & wood & Cantrill and Poole, 2004 \\
\hline & Laurelites jamesrossii & $\begin{array}{l}\text { Laureliopsis } \\
\text { philippiana }\end{array}$ & wood & Cantrill and Poole, 2004 \\
\hline Chloranthaceae & & Ascarina & pollen & $\begin{array}{l}\text { Dettmann and Thomson, 1987; } \\
\text { Dettmann, } 1989\end{array}$ \\
\hline \multirow[t]{2}{*}{ Cunoniaceae } & $\begin{array}{l}\text { Weinmannioxylon } \\
\text { nordenskjoeldii }\end{array}$ & Weinmannia & wood & Cantrill and Poole, 2004 \\
\hline & $\begin{array}{l}\text { Weinmannioxylon } \\
\text { ackamoides }\end{array}$ & Ackama & wood & Cantrill and Poole, 2004 \\
\hline Illiciaceae & Illicioxylon & Illicium & wood & Cantrill and Poole, 2004 \\
\hline
\end{tabular}


Table 2 (continued)

\begin{tabular}{|c|c|c|c|c|}
\hline Family & Morphotaxa & Nearest living relative & Organ & Reference \\
\hline \multicolumn{5}{|c|}{ Coniacian to Campanian (James Ross Basin) } \\
\hline Lauraceae & Sassafrasoxylon & Sassafras & wood & Cantrill and Poole, 2004 \\
\hline Loranthaceae & Cranwellia striata & & pollen & Askin, 1989 \\
\hline Monimiaceae & $\begin{array}{l}\text { Hedycaryoxylon } \\
\text { tambourissoides }\end{array}$ & Hedycarya & wood & Cantrill and Poole, 2004 \\
\hline Myrtaceae & & - & pollen & Dettmann, 1989 \\
\hline \multirow[t]{2}{*}{ Nothofagaceae } & $\begin{array}{l}\text { Nothofagoxylon } \\
\text { scalariforme }\end{array}$ & $\begin{array}{l}\text { Nothofagus } \\
\text { antarctica }\end{array}$ & wood & Cantrill and Poole, 2004 \\
\hline & & - & pollen & Dettmann and Thomson, 1987 \\
\hline \multirow[t]{5}{*}{ Proteaceae } & & Macadamia & pollen & $\begin{array}{l}\text { Dettmann and Thomson, 1987; } \\
\text { Dettmann, } 1989\end{array}$ \\
\hline & & Gevuina-Hicksbeachia & pollen & Dettmann and Jarzen, 1991 \\
\hline & & Adenanthos barbigera & pollen & Dettmann and Jarzen, 1991 \\
\hline & & Telopea truncata & pollen & Dettmann and Jarzen, 1991 \\
\hline & & Carnarvonia & pollen & Dettmann and Jarzen, 1991 \\
\hline
\end{tabular}

Data from the Antarctic Peninsula region-Senonian to middle Eocene-divided into floral assemblages which might characterise changing climate based on the pollen and wood floral assemblages. Leaf data has not been included because they comprise of compression fossils lacking the necessary cuticles for definitive identifications.

other) plant taxa (Cantrill and Poole, 2002) factors other than climate alone would probably have affected angiosperm wood evolution. This also illustrates the problems of extrapolating from modern floras into the past especially back into the Mesozoic. With these considerations in mind the inferred palaeoclimate data should be interpreted with care and reference to associated caveats duly acknowledged.

\subsubsection{Coexistence approach}

All identified conifer and angiosperm wood material and identified palynological and leaf material (Table 2) from specific floras were subject to the Coexistance Approach (CA) (Mosbrugger and Utescher, 1997). This approach applies climate tolerances of all nearest living relatives (NLRs) known for a fossil flora to determine intervals for a variety of climate variables in which most of the taxa can coexist. The resulting intervals are then used to define the palaeoclimate conditions for the fossil flora (cf. Mosbrugger and Utescher, 1997). Since this method is based on the NLR concept, the approach is suited for climate reconstructions from the Cenozoic palaeobotanical record where it has proved its reliability. The climatic resolution obtained from the method (i.e. the widths of the intervals) strongly depends on the number of NLR-taxa contributing with climate data, as well as the taxonomic level of identification of NLRs. The percentages of NLR-taxa coexisting in the resulting climate intervals are considered as a measure of the significance of the results obtained. Theoretically, $100 \%$ of the NLRs of a fossil flora should coexist. In practice, percentages range between $85 \%$ and $100 \%$ for Tertiary floras (Utescher et al., 2000) because of the number of potential biasing factors. Important sources of error include: the taphonomic conditions of the fossil flora; the misidentification of NLRs; the fact that certain NLRs, such as monotypic genera or relicts occurring in isolated areas may not represent the entire climatic spectrum of their ancestors; and the proposed underestimation of CMMT (by $1.5-3{ }^{\circ} \mathrm{C}$ for the taxa studied) when derived from the NLR approach in periods where atmospheric $\mathrm{CO}_{2}$ levels were higher than today (Royer et al., 2002). However with respect to the latter, the absence of such studies on the taxa included herein and species-specific relationship between atmospheric $\mathrm{CO}_{2}$ level and sensitivity remains unclear with respect to CMMT, corrections or adjustments during a period of strong $\mathrm{CO}_{2}$ fluctuation remain difficult and have not been undertaken. The last two sources of error especially become increasingly important with the age of the floras analysed and diminish the significance of the results - a fact which has to be kept in mind when interpreting the data calculated for the Mesozoic floras.

A list of the taxa in each flora analysed are given in Table 2 and are derived from a number of published 
Table 3

Summary of the quantitative palaeoclimate data published to date from King George Island (KGI) and the James Ross Basin (JRB)

\begin{tabular}{|c|c|c|c|c|c|c|c|c|c|c|}
\hline & \multirow[t]{2}{*}{ Method } & \multicolumn{2}{|l|}{ Middle Eocene KGI } & \multirow{2}{*}{$\begin{array}{l}\text { Early Eocene } \\
\text { JRB }\end{array}$} & \multirow{2}{*}{$\begin{array}{l}\text { Latest Early } \\
\text { Paleocene }\end{array}$} & \multirow{2}{*}{$\begin{array}{l}\text { Early } \\
\text { Paleocene }\end{array}$} & \multirow{2}{*}{$\begin{array}{l}\text { Late } \\
\text { Maastrichtian }\end{array}$} & \multirow{2}{*}{$\begin{array}{l}\text { Coniacian- } \\
\text { Campanian }\end{array}$} & \multirow{2}{*}{$\begin{array}{l}\text { Santa } \\
\text { Marta }\end{array}$} & \multirow{2}{*}{$\begin{array}{l}\text { Hidden } \\
\text { Lake }\end{array}$} \\
\hline & & Dragon Glacier & Fossil Hill & & & & & & & \\
\hline \multicolumn{11}{|l|}{ Temperature } \\
\hline \multirow[t]{6}{*}{ MAT, ${ }^{\circ} \mathrm{C}$} & LMA & 10.5 & 8.8 & - & - & - & - & - & $16-23$ & $15-20$ \\
\hline & CLAMP & 10.6 & - & - & $13.5 \pm 0.7$ & - & - & - & - & - \\
\hline & WP mean (n) & - & $11.7(*)$ & $10.9(*)$ & $14.7(*)$ & $9.9(*)$ & $11.1(*)$ & $13.5(*)$ & - & - \\
\hline & CA flora & - & $12.2-12.6-13.0$ & $14.8-16.1-17.4$ & $11.1-14.6-18.1$ & $12.2-12.6-13$ & $13.9-16-18.1$ & $12.9-17.1-21.3$ & - & - \\
\hline & CA leaves & $14.8-15.2$ & $13.8-26.5$ & - & - & - & - & - & - & - \\
\hline & mean & 12.0 & 13.3 & 13.5 & 14.2 & 11.3 & 13.6 & 15.3 & & \\
\hline MART, ${ }^{\circ} \mathrm{C}$ & $\mathrm{WP} \pm 1.4^{\circ} \mathrm{C}$ & - & 10.7 & 11.7 & 8.2 & 9.5 & 9.7 & 3.4 & - & - \\
\hline \multirow[t]{2}{*}{$\mathrm{CMMT},{ }^{\circ} \mathrm{C}$} & $\mathrm{WP} \pm 2.6^{\circ} \mathrm{C}$ & - & 11.6 & 7.1 & 10.3 & 10.4 & 8.2 & 29.0 & - & - \\
\hline & $\begin{array}{l}\text { CA flora } \\
\text { (CA leaves) }\end{array}$ & $-(9.2-10.8)$ & $\begin{array}{l}7.6-7.65-7.7 \\
(7.8-25.3)\end{array}$ & $7.6-7.65-7.7$ & $7.6-7.65-7.7$ & $7.6-9.7-11.8$ & $7.4-8.3-9.1$ & $7.4-7.6-7.8$ & - & - \\
\hline WMMT, ${ }^{\circ} \mathrm{C}$ & $\begin{array}{l}\text { CA flora } \\
\text { (CA leaves)[CLAMP] }\end{array}$ & $(20.4-27.0)[19.0]$ & $\begin{array}{l}16.3-16.6-17 \\
(20.4-27.0)\end{array}$ & $22.8-23.3-23.9$ & $15.2-19.6-23.9$ & $16.3-17.1-18$ & $18.5-21.8-25$ & $22.3-24.7-27$ & - & - \\
\hline DRY & $\mathrm{WP} \pm 1.4$ months & - & -10.5 & -5.4 & -9.0 & -6.5 & -7.9 & -10.7 & - & - \\
\hline \multicolumn{11}{|l|}{ Precipitation } \\
\hline \multirow{5}{*}{ MAP, mm } & LMA & 1039 & 1059 & - & - & - & - & - & - & - \\
\hline & CLAMP & 885 & - & - & - & - & - & - & $590-2570$ & $540-2720$ \\
\hline & $\mathrm{WP} \pm 940 \mathrm{~mm}$ & - & 3707 & 3889 & 2548 & 4225 & 4944 & 5620 & - & - \\
\hline & CA flora (leaves) & $-(615-1250)$ & $\begin{array}{l}652-733-815 \\
(815-2099)\end{array}$ & $652-733-815$ & $574-894-1215$ & $652-671-691$ & $652-928-1205$ & 887-947-1008 & - & - \\
\hline & mean & 952 & 1739 & 2311 & 1721 & 2448 & 2936 & 3284 & 1580 & 1630 \\
\hline $\mathrm{WM}, \mathrm{mm}$ & CA flora & - & $74-128.5-183$ & $86-134.5-183$ & 58-120.5-183 & $148-165.5-183$ & $87-135-183$ & 183-185-187 & - & - \\
\hline \multirow[t]{3}{*}{$\mathrm{DM}, \mathrm{mm}$} & CA flora & - & $25-31-37$ & $25-31-37$ & $25-27-29$ & $17-23-29$ & $25-33.5-42$ & $19-31.5-44$ & - & - \\
\hline & VI & - & 0.85 & 0.57 & 0.59 & 0.62 & 0.83 & 1.98 & - & - \\
\hline & MR & - & 552 & 299 & 321 & 341 & 389 & 1332 & - & - \\
\hline
\end{tabular}

Temperature data: MAT, mean annual temperature; MART, mean annual range in temperature; CMMT, cold month mean temperature; WMMT, warm month mean temperature. Data derived from leaf margin analysis (LMA), CLAMP, wood physiognomy (WP), Coexistence Analysis (CA; minimum-mean-maximum values) based on total flora (CA flora) this study and of just leaf flora (CA leaves). DRY, length of dry season. Precipitation data: MAP, mean annual precipitation; WM, wettest month; DM, driest month derived abbreviations as for temperature data. VI, vulnerability index; MR, mesomorphy ratio. Data derived from this study except for climate data derived from Santa Marta Formation and Hidden Lake Formation leaf floras (Hayes, 1999), Dragon Glacier flora (Hunt, 2001) and data derived from the Fossil Hill leaf flora (Hunt, 2001), latest Early Paleocene leaf flora (Francis et al., 2003). See text for details. 
and unpublished sources. In order to obtain a diversity of greater than 10 NLR taxa, the level commonly required by the $\mathrm{CA}$, the paleobotanical record of particular time intervals have been combined, and mega- and microfloral remains are analysed together. In most of the cases the number of taxa contributing with climate data is sufficiently high (14-33 taxa) such that reliable results can be expected. For the Cross Valley flora, with a diversity of only 7 taxonomic diversity is below the lower limit. The climate data calculated are summarized in Table 3. With a mean interval width of $4.0{ }^{\circ} \mathrm{C}$ for MAT the climatic resolution is considerably lower when compared with ranges of ca. $1.5{ }^{\circ} \mathrm{C}$ obtained from the analyses Neogene floras (Utescher et al., 2000). As expected, only rarely did all NLRs of the fossil taxa coexist within the resulting ranges (see above). Additional uncertainties arise from the fact that the single floras analysed represent longer time-spans (up to a few million years) in which short-term climate variations might have been present. In addition, the combined analyses of woods and pollen although representative of a more complete regional flora could still be biased by associated taphonomical factors. However, the percentages of coexisting taxa in the majority of cases are above $85 \%$ and the results can be regarded as highly significant. In 12 of 36 cases the data are less reliable with percentages of coexisting taxa falling between $71 \%$ and $85 \%$ (i.e. KGI and latest Early Paleocene floras). As shown by the analyses of the single floras there are three permanent climatic outliers observed which are partly responsible for these inconsistencies. These are Beauprea presently restricted to New Caledonia, Cupania and Macadamia, both growing today in much warmer climates.

\section{Results}

\subsection{Climate signals from growth characters}

\subsubsection{Conifer woods}

One feature typifying the coniferous wood is the relatively narrow late wood zone of just a few cells. This is a feature of high latitude coniferous wood and has been suggested to be a function of day length induced dormancy (since these latitudes experience one month of total winter darkness and light induced photoinhibition for several weeks either side) rather than limiting growing conditions such as water availability or cold temperatures (Parish and Spicer, 1988). Within the araucarian wood, a group that generally has weakly developed rings, this feature is well developed. Araucarioxylon and Araucariopitys from Williams Point (Livingston Island) have wide $(0.8-5.0 \mathrm{~mm})$, well-defined growth rings but with only a few late wood cells (2-4). Well-defined rings are also seen in the Late Maastrichtian although a few specimens $(20 \%)$ have growth interruptions (defined as a few, ca. 2-4, cells with reduced dimensions forming a visible interruption in growth but not similar in magnitude or extent to a true ring) within each annual ring cycle. This percentage increases in the Early Paleocene and by the late Early Paleocene had risen to $40 \%$ of the specimens. This suggests that environmental conditions such as water availability or temperature became limiting for short periods during the growing season resulting in a slowing in growth. By the Early Eocene and into the Middle Eocene the percentage of specimens with growth interruptions declines (to ca. 20\%), but the characteristics of the ring boundary changes. In general the late wood zone expands in width and cell walls become thicker. Thick cell walls in the late wood are more typical of conifers from temperate regions where water becomes limiting in the later part of the growing season. This suggests the control of the growing season changes from being light induced in the mid-Cretaceous to being caused by limiting factors such as temperature and/or water availability. This would be consistent with changes from a warm mid-Cretaceous interval to cooler Paleogene period.

It might be expected that given the high palaeolatitude and the associated seasonal darkness, frostincluding (unseasonally) early or late frosts-would be part of the climatic regime manifesting itself as areas of frost damage or false rings (defined here as a more pervasive interruption in growth resembling to the greater extent true rings). Within this dataset only one ring with disorganized cell growth and traumatic parenchyma was observed in the araucarian conifers even though Chapman and Smellie (1992) recorded false rings in $75 \%(n=8)$ of the podocarpaceous and araucariaceous wood taxa described from Livingston Island and Jefferson (1982) noted the presence of frost damage in conifer woods from the more southerly 
Alexander Island. Most false rings do not appear to be the result of severe frosts resulting in cell death but rather short term interruptions to cell expansion.

Recent studies have demonstrated that frost rings are remarkably rare even within trees growing in regions with significant frosts and when present are confined to the outer twigs and branches and early ontogenetic stages of the upper trunk and branch wood and absent from mature trunk wood (Chapman, 1994; Falcon-Lang, 2005). Moreover elevated atmospheric $\mathrm{CO}_{2}$ concentrations (DeConto and Pollard, 2003) present at this time have been hypothesised to increase plant frost sensitivity by raising the temperature at which the leaf tissues freeze (Beerling et al., 2002) and thus increasing the likelihood of frost ring formation. The conifer wood studied here are generally from large branches and possibly trunk wood and thus may have been protected from any unseasonally late frosts although given the higher than ambient atmospheric $\mathrm{CO}_{2}$ concentrations it seems unlikely that near freezing temperature (unseasonally cold conditions) were experienced after the onset of the growing season. This is perhaps not that surprising given the palaeogeographic setting close to the sea would have resulted in a more maritime climate with the consequent dampening of extreme temperature variability relative to continental climates.

\subsubsection{Angiosperm woods}

If light and/or temperature were the limiting environmental factor the incidence of rings exhibiting deferred optimum vessel diameter might be assumed to be high. Moreover unfavourable conditions during the growing season would manifest itself as a false ring (see Section 3.1.1). In the Coniacian-Campanian warm period there is no evidence for DOVD or growth interruptions suggesting that growth resumed uninterrupted when all requirements were above the minimum threshold.

In the Late Maastrichtian the incidence of DOVD is at its greatest (32\%) suggesting light and/or temperature were controlling factors in the southern latitude environment. Following this peak, the incidence of DOVD gradually decreases from the Late Maastrichtian through the Early Paleocene to the Middle Eocene (11\%) suggesting an increased acclimation of the angiosperms to the high latitude environments.
The angiosperm wood, unlike that of the conifer material, records the presence of growth interruptions from the Late Maastrichtian with an increase in the Eocene. This might imply that not all conditions remained favourable for the angiosperms. If temperature were a likely candidate, this could be discounted since these taxa are evolving under falling palaeoatmospheric $\mathrm{CO}_{2}$ concentrations, which would make them less sensitive to unseasonal fluctuations in temperature relative to the conifers. Alternatively, the occurrence of growth interruptions might suggest once more that the angiosperms were not totally adapted to these high latitude palaeoenvironments.

The vast majority of angiosperm woods from the Maastrichtian to Eocene have semi-ring porous woods and distinct, albeit narrow, growth rings. Only in the Coniacian-Campanian warm period does the diffuse porous condition dominate with the oldest angiosperm woods described (i.e. from Williams Point, Livingston Island; Poole and Cantrill, 2001) exhibiting both diffuse porosity and indistinct growth rings. Ring porosity is most obvious in Sassafrasoxylon from the Late Cretaceous (Poole et al., 2000). This is the earliest know occurrence of ring porosity suggesting that this condition might have evolved in response to the seasonal high latitude environment.

The virtual absence of ring porosity, coupled with the high incidence of indistinct growth rings in the Coniacian-Campanian material, from plants growing in the highly seasonal Antarctic environment suggests that the associated physiological responses may have only evolved across taxa in general during the later Tertiary. This supports the conclusion drawn by Wheeler and Baas (1991). Therefore the use of growth characters in wood, often associated with general ecological variables, for climatic determination prior to the Tertiary may be confounded by the incomplete evolution of adaptational strategies.

\subsection{Multivariate anatomical analyses}

Five climate variables MAT, MART, CMMT, MAP and DRY were determined (Table 1). The negative values for DRY for the six floras can be explained by the complete absence of a distinct dry season from the Late Cretaceous through to the Middle Eocene. The predictions of CMMT derived from wood physiognomy range from $29{ }^{\circ} \mathrm{C}$ in the Coniacian to 
Campanian warm period to ca. $7{ }^{\circ} \mathrm{C}$ in the Early Eocene (Table 1). The evidence of frost and ice mass accumulation in Antarctica during the Eocene (Zachos et al., 2001) implies that the CMMT for the Eocene, at least, are overestimates. Moreover considering that the estimated CMMTs are often greater (50\%) than the mean MAT (Table 3) coupled with the conclusions of Wiemann et al. (1998b) who state that CMMT is less precise than other climate variables, these values are considered to be too imprecise, especially for the Coniacian-Campanian material, to warrant further discussion but have been included for completeness.

MART values obtained here range from ca. $3.5^{\circ} \mathrm{C}$ in the Coniacian-Campanian to ca. $12{ }^{\circ} \mathrm{C}$ in the late Early Eocene (Table 1). These data suggest that the Coniacian-Campanian was equable all year but became more seasonal in the Eocene. However, it would be expected that given the length of winter darkness experienced at these latitudes, MARTs would be greater than $3{ }^{\circ} \mathrm{C}$ even in a period of relative warmth and greater than $12{ }^{\circ} \mathrm{C}$ during the Eocene cooling. Wiemann et al. (1998b) also conclude that MART is less precise than other climate variables and are therefore recorded here for completeness but will not be discussed further.

The relative shifts in MAP (Table 1, Fig. 2) show a progressive drying of the climate from the ConiacianCampanian into the Late Paleocene with a sharp decrease in the late Early Paleocene. Thereafter annual precipitation levels rise again into the Middle Eocene before falling again in the later middle Eocene. Wiemann et al. (1998b) state that MAP values derived in this way are probably overestimated. Therefore relative shifts may be more reliable than absolute values. Interestingly the Vulnerability Index and Mesomorphy Ratio also indicate a wetter Coniacian-Campanian period relative to the Late Maastrichtian and Tertiary (Table 1) suggesting that the trends may be real.

Mean annual temperatures derived from the abundance of individual anatomical characters show no logical trend with MAT derived for the 37 regions analysed by Wiemann et al. (1998b) (Fig. 3). Therefore we do not consider the abundance of individual characters alone to be a reliable technique to enhance understanding of palaeotemperatures. The MAT estimates derived from abundance data of anatomical character combinations in the equations given in Table
1 (from Wiemann et al., 1998b). The data from Eqs. (15) and (16) were not used since the MATs of 26-45 ${ }^{\circ} \mathrm{C}$ (Eq. (16)) are considered too high relative to data derived from independent sources (see below) whereas estimates of MAT of $0.6{ }^{\circ} \mathrm{C}$ (Eq. (15)) for the Coniacian-Campanian are considered to be unrealistically low therefore all data derived from these two equations have been excluded from further analysis. The remaining data, along with the calculated mean MAT, are plotted in Fig. 4. Although the absolute temperatures given by the formulae differ, there is a general underlying trend in the directionality of the temperature excursions (Table 1, Fig. 4). Fig. 4 indicates the Coniacian-Campanian was a period of relative warmth with the mean MAT estimated to be up to $13.5^{\circ} \mathrm{C}$ (Table 3 ). The Late Maastrichtian is slightly cooler with mean MATs of ca. $11^{\circ} \mathrm{C}$. A warming trend develops from ca. $10{ }^{\circ} \mathrm{C}$ the Early Paleocene to ca. 15 ${ }^{\circ} \mathrm{C}$ in the late Early Paleocene. The Eocene is characterised by cooler conditions once again (ca. 11$12{ }^{\circ} \mathrm{C}$ ). These data are compared with other published MAT estimates in Table 3 and discussed below.

\subsection{Coexistence approach}

The climate variables MAT, CMMT, warm month mean temperature (WMMT), MAP as well as precipitation in the wettest and driest month were determined by the Coexistence Approach (Table 3 and Fig. 2). The significance of the climate data obtained from the Coexistence Approach (CA) is not as rigorous as for data obtained from Neogene material due to the additional problems associated with climatic tolerance variations through geological time. With this caveat in mind the data obtained can be compared with those using the wood anatomy of the angiosperm samples and other climate data derived from plant proxies (Figs. 2 and 5).

All temperature variables analysed by the CA indicate that warm conditions existed during the Coniacian-Campanian with MAT, CMMT and WMMT decreasing slightly into the Maastrichtian. In the earliest Paleocene a significant drop of MAT and WMMT are observed followed again by a warmer phase in the late Early to early Middle Eocene. In the Middle Eocene temperatures again decrease. The warm month mean shows the most significant variations in terms of palaeotemperature which is contrary 

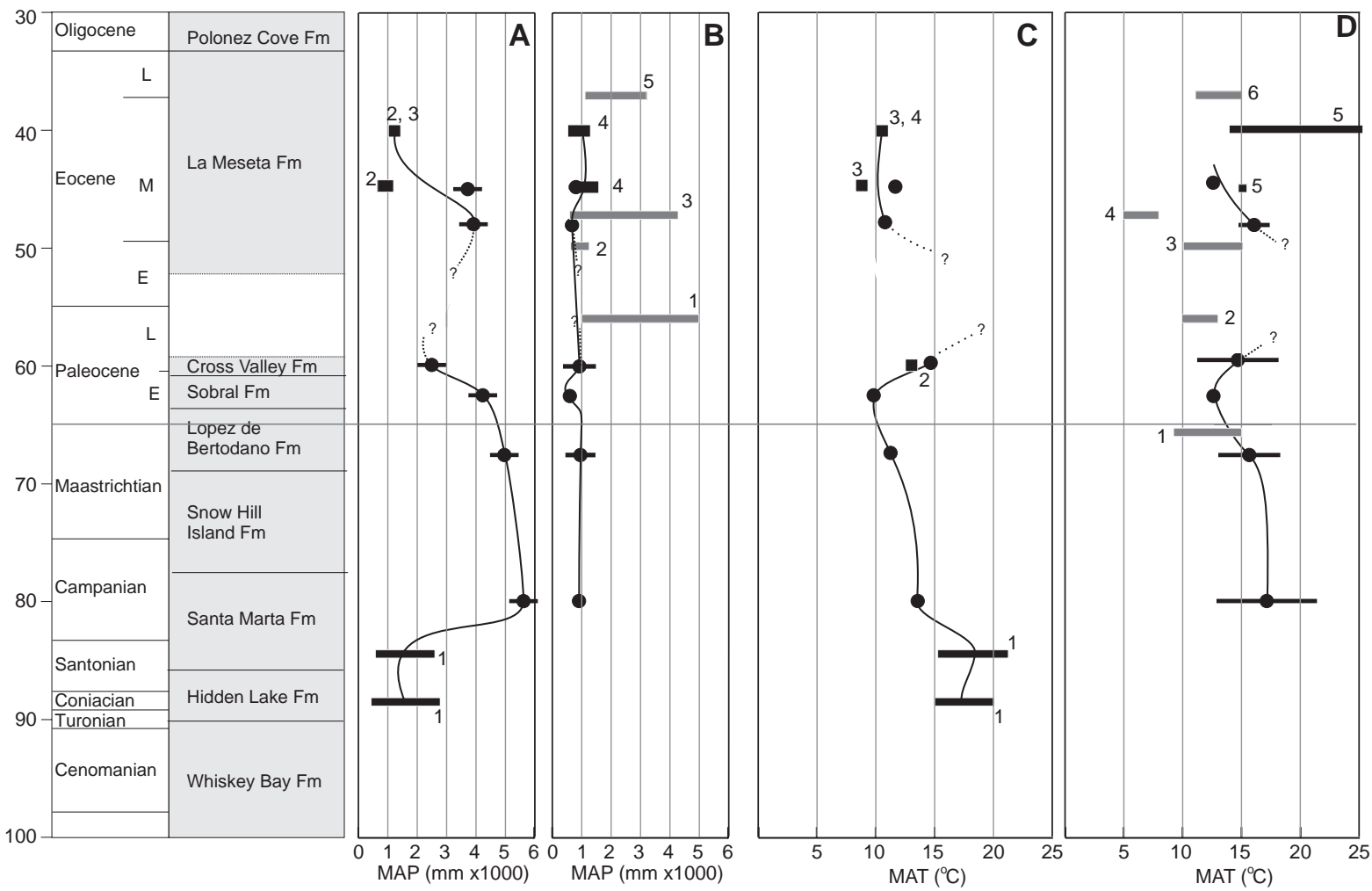

Fig. 2. Compilation of data showing the change in terrestrial climate in terms of mean annual precipitation (MAP mm) and mean annual temperature (MAT ${ }^{\circ} \mathrm{C}$ ) with range/error when greater than the data point from the Coniacian-Campanian to Middle Eocene for the Antarctic Peninsula region. See Table 2 for details. (A) MAP curve based on quantitative data derived from wood physiognomy (black circles) and leaf physiognomy given in ${ }^{1}$ Hayes (1999), ${ }^{2}$ Hunt (2001), ${ }^{3}$ Hunt and Poole (2003). (B) MAP curve based on quantitative data calculated by the Coexistence Approach from this study (black circles) and from fossil leaf floras (black rectangle) given in ${ }^{4}$ Hunt (2001) and estimates derived from nearest living floras (grey rectangles) after ${ }^{1}$ Birkenmajer and Zastawniak (1989) Late Cretaceous-early Palaeogene (56.8 $\pm 1.2 \mathrm{Ma}$ ) Dufayel Island (KGI) flora (1000-4000 mm), ${ }^{2}$ Doktor et al. (1996) Late Paleocene-Eocene floras of Seymour and KG Islands (600-1200 mm), ${ }^{3}$ Birkenmajer and Zastawniak (1989) Eocene (47 $\pm 2 \mathrm{Ma}$; dating updated from Hunt, 2001) Point Hennequin floras (600-4300 mm), ${ }^{5}$ Birkenmajer and Zastawniak (1989) for the Late Eocene (37.4 $\left.1.1 \mathrm{Ma}\right)$ Cytadela flora (1220-3225 mm). (C) Mean MAT curve derived from wood physiognomy equations (see Table 1 and text for details, black circles) and quantitative data from leaf physiognomy (black squares) given in ${ }^{1}$ Hayes (1999), ${ }^{2}$ Francis et al. (2003), ${ }^{3}$ Hunt (2001), ${ }^{4}$ Hunt and Poole (2003). (D) MAT curve based on quantitative data calculated by the Coexistence Approach in this study (black circles) and from leaf floras (black rectangles) given in ${ }^{5}$ Hunt (2001) and estimates derived from nearest living floras (grey rectangles) after ${ }^{1}$ Askin (1992) latest Maastrichtian $\left(8-15{ }^{\circ} \mathrm{C}\right),{ }^{2}$ Birkenmajer and Zastawniak (1989) Late Cretaceousearly Palaeogene $(56.8 \pm 1.2 \mathrm{Ma})$ Dufayel Island (KGI) flora $\left(10-13{ }^{\circ} \mathrm{C}\right),{ }^{3}$ Doktor et al. (1996) Late Paleocene-Eocene floras of Seymour and KG Islands $\left(10-15^{\circ} \mathrm{C}\right),{ }^{4}$ Birkenmajer and Zastawniak (1989) Eocene (47 $\pm 2 \mathrm{Ma}$; dating updated from Hunt, 2001) Point Hennequin floras (5-8 $\left.{ }^{\circ} \mathrm{C}\right),{ }^{6}$ Birkenmajer and Zastawniak (1989) for the Late Eocene $(37.4 \pm 1.1 \mathrm{Ma})$ Cytadela flora $\left(11.7-15{ }^{\circ} \mathrm{C}\right)$.

to that found in studies utilising the CA on Tertiary floras from the mid-latitudes (e.g. Utescher et al., 2000). Moreover the maximum estimated temperatures do not surpass $27{ }^{\circ} \mathrm{C}$. Once again there is a sharp decrease over the $K-T$ boundary from a relatively warm WMMT (ca. $21.8{ }^{\circ} \mathrm{C}$ ) during the Maastrichtian decreasing to ca. $17^{\circ} \mathrm{C}$ by the earliest Paleocene.

Annual precipitation (MAP) levels during the time interval under discussion here are relatively constant.
Estimates derived from CA are consistently over 575 $\mathrm{mm}$ and mean annual levels generally above $700 \mathrm{~mm}$. The VI and MR suggest that during the ConiacianCampanian was a period of relative abundant water availability but these levels had roughly halved by the Maastrichtian and continued to remained relatively dry throughout the Early Tertiary. The CA undertaken in this study however suggests relatively constant MAP in the Coniancian-Campanian and Maastrichtian (ca. 

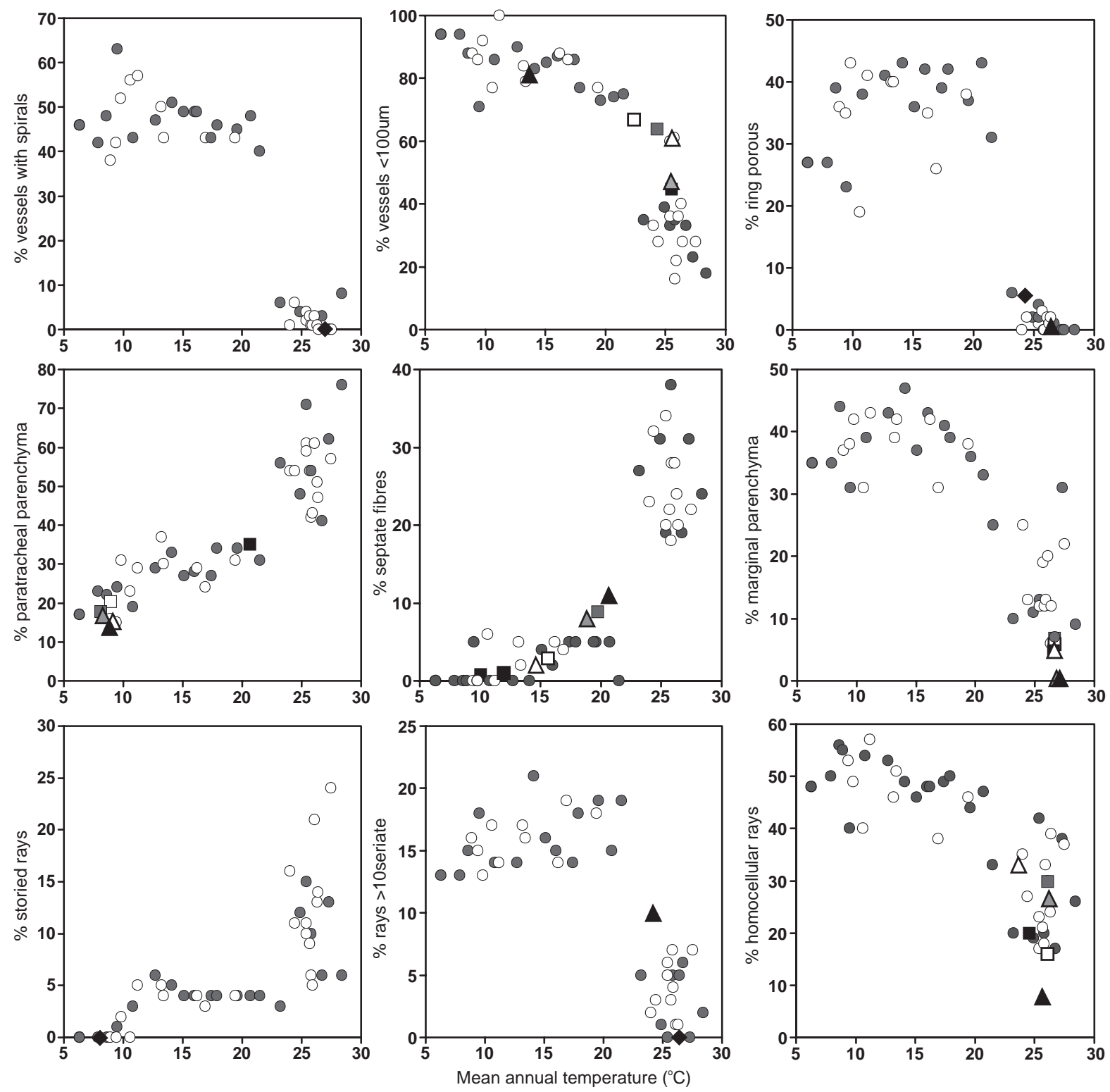

Fig. 3. Frequency of wood anatomical characters (circles) as a function of site MAT (redrawn and adapted from Wiemann et al., 1999 where closed circles represent those sites used to derive the equations and open circles represent the validation sites). Frequency of wood anatomical characters of each fossil flora studied herein have been plotted - open square, Middle Eocene; grey square, Early Eocene; closed square, latest Early Paleocene; open triangle, Early Paleocene; grey triangle, Late Maastrichtian; closed triangle, Coniacian-Campanian; closed diamond, all (or remaining) sites.

$900 \mathrm{~mm}$ ) but with a decrease in the early Paleocene (ca. $700 \mathrm{~mm}$ ) with levels returning to Cretaceous levels in the latest Early Paleocene. MAPs remained fairly constant until the Middle Eocene. Leaf margin analyses and CA analyses of leaf floras suggested a relatively high MAP of $>1000 \mathrm{~mm}$ for the Middle Eocene (Hunt and Poole, 2003) whereas the CA of the total flora estimates a level of ca. $700 \mathrm{~mm}$ (Table 3). Valdivian ecosystems (the closest living analogue to these Antarctic floras; Poole et al., 2001, 2003) 


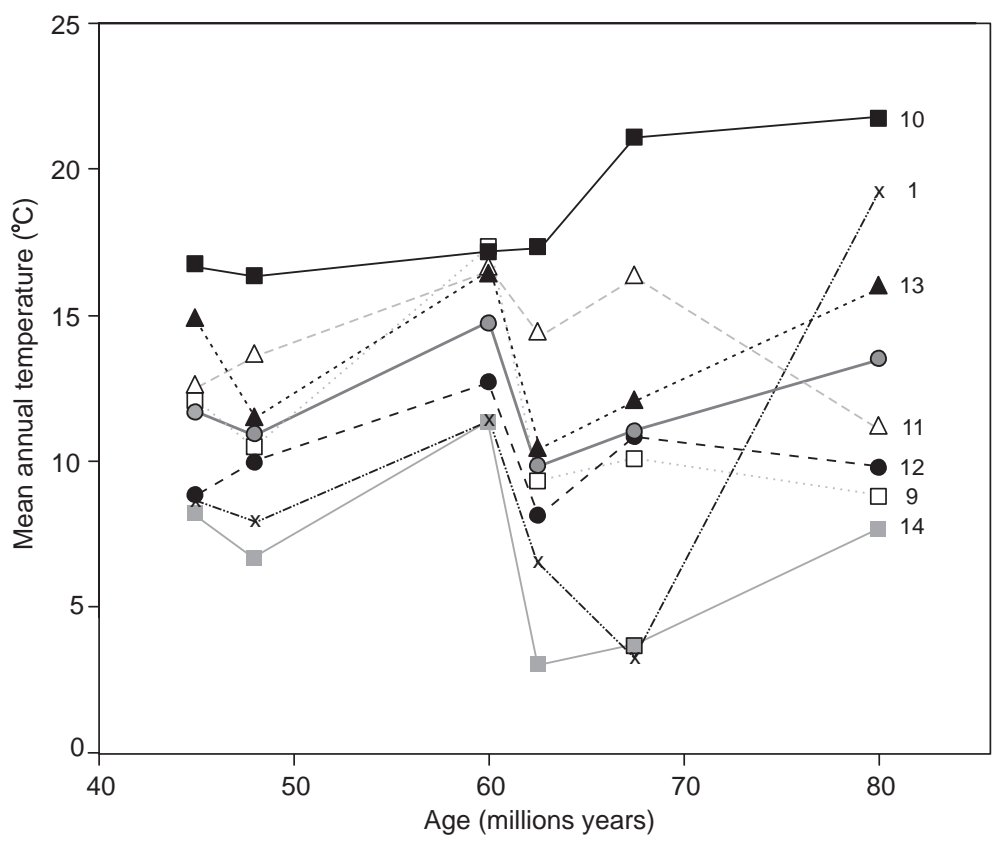

Fig. 4. Results for mean annual temperature derived from different formulae (numbers refer to the formulae defined in Table 1). Grey circles indicate the mean value of the data for each stage referred to in the text.

however are supported today in areas where MAP is between 900 and $2500 \mathrm{~mm}$ (Ohga, 1987), so $700 \mathrm{~mm}$ is a somewhat low estimate. Nevertheless, moisture may have been introduced to the system through means other than direct precipitation, i.e. sea mists, etc., given the proximity of the sea and probable maritime climate. The results obtained for the precipitation rates in the wettest and driest month, respectively, point to a pronounced seasonality. For the driest month, mean precipitation rates remain fairly constant ranging between 27 and $34 \mathrm{~mm}$, except in the Early Paleocene where precipitation of the driest month was $23 \mathrm{~mm}$. For the wettest month very high rates of around $185 \mathrm{~mm}$ are calculated for the ConiacianCampanian (range 183-187 mm), decreasing into the Maastrichtian (range 87-183 mm, mean $135 \mathrm{~mm}$ ). In the later Paleocene and in the Eocene, relatively wide ranges of wet month precipitation occur (range 58$183 \mathrm{~mm}$, mean $121 \mathrm{~mm}$ ) suggesting greater variability.

In summary therefore, it seems that warm, permanently wet conditions (Fig. 2) reflecting a warm temperate/subtropical environment were at an optimum in the Coniacian-Campanian. MATs then decreased to the end of the Maastrichtian (Fig. 2), accompanied by a decrease in the WMMT and CMMT (Table 3), i.e. more warm/cool temperate, but still relatively wet conditions prevailing throughout this time. This is followed by a decrease in both MAT and MAP combined with reduced mean precipitation of the driest month (more cool temperate) by the earliest Paleocene (Table 3). WMMT continued to fall across the KT boundary (Table 3). MATs increased through the Paleocene (reflecting a possible return to warm temperate conditions) and remained relatively high until the Middle Eocene (Fig. 3 ) when they began their final demise as glaciation in East Antarctica began. MAP levels had increased by the Eocene and then underwent a decrease through the middle Eocene. CMMT levels remained fairly constant after the Early Paleocene-only the WMMT data show an increase to the end of the Early Eocene before decreasing once again (Table 3 ).

3.4. Comparison of the results obtained from the different approaches

Conifer wood characters document a growing season dictated by light in the Late Cretaceous and 
probably by temperature in the Eocene, this is also implied from wood characters of angiosperm wood although this ecological signal may be confounded by evolutionary and adaptational processes associated with angiosperm evolution at this time.

Multivariate anatomical analyses and Coexistence Approach both suggest a relatively warm, wet Late Cretaceous becoming much cooler and drier at the very end of the Maastrichtian into the early Paleocene (Fig. 2). The results obtained from the VI and MR regarding relative degree of wetness in the environment are also in agreement. The driest phase is considered to be the early to middle Paleocene as determined from $\mathrm{CA}$ and multivariate anatomical analysis. In the Eocene results from the multivariate anatomical analysis suggest a drier climate whereas those derived from the CA suggests a continuation of the relatively low precipitation levels. With regard to temperature both approaches resulted in similar trends with a warming from the early Paleocene followed by cooling, after the hiatus, into the middle Eocene. Absolute values in MAP and MAT differ between these two approaches with the greatest discrepancy occurring in the Late Cretaceous and Early Eocene. In the Paleocene and Middle Eocene the mean estimates are within $2.5{ }^{\circ} \mathrm{C}$. Interestingly nearest living relative estimates (grey bars in Fig. 2) show no relationship to the data derived herein with regard to MAP but do show a general decline in MAT during the middle Eocene similar to that obtained from the CA.

In conclusion therefore although the results obtained from the different approaches differ, the general trends observed from the CA and multivariate anatomical analysis are in general concordance and may be used to infer palaeoclimatic trends in Antarctica at this time.

\section{Discussion}

\subsection{Implications for growth in the high southern latitudes}

During the Cretaceous and Tertiary, the Antarctic Peninsula region was the site of an active continental arc. The geology suggests a narrow peninsula with a central range of mountains. Although we have no direct evidence for the heights of the mountains they were probably in the order of 2000-3000 m-similar to those seen in similar continental arcs such as Japan today. Bordering an ocean, and lying at latitude 59$62^{\circ} \mathrm{S}$ (Lawver et al., 1992), the Antarctic Peninsula lay in the path of a westerly air stream and this coupled with the topography would have resulted in a strong orographic control on rainfall. The closest setting would be similar to that seen in Tasmania (latitude $41-43^{\circ} \mathrm{S}$ ) today where the contrast in annual rainfall between the west $(3600 \mathrm{~mm})$ and east $(500$ $\mathrm{mm})$ is great. Other such settings occur in South Island, New Zealand $\left(41-47^{\circ} \mathrm{S}\right)$ where $4000-12000$ $\mathrm{mm}$ of rain falls in the west versus $300-800 \mathrm{~mm}$ in the east, or southern south America $\left(48-53^{\circ} \mathrm{S}\right)$ which has $4000-8000 \mathrm{~mm}$ in the west versus $200-500 \mathrm{~mm}$ in the east. However, being surrounded by water masses on both sides, the Antarctic palaeoclimate would have been maritime with reduced contrasts in temperature and precipitation throughout the year.

Vegetation growing on the active arc also experienced strong environmental disturbance as a result of arc processes. Volcanic eruption and ecosystem disturbance played a major role and strongly influenced vegetation composition (Poole et al., 2001). As vegetation composition determines the taxa preserved and therefore analysed, these processes can potentially bias the climate signal. This is also true for environmental processes as increases in volcanic frequency change soil conditions and probably influence water availability.

Growing at a palaeolatitude of ca. $60^{\circ} \mathrm{S}$ (Lawver et al., 1992) and experiencing higher than ambient atmospheric $\mathrm{CO}_{2}$ concentrations, plant physiological processes would have differed from plants growing at any location on Earth today. The vegetation would have experienced a dormant phase (of at least 1 month) as a result reduced light intensity which was probably limiting for a number of weeks either side of the period of total winter darkness. Temperature extremes may have been buffered by the high atmospheric $\mathrm{CO}_{2}$ (up to $2000 \mathrm{ppm}$ in the Late Paleocene and Early Eocene; Pearson and Palmer, 2000) coupled with the maritime setting, thereby keeping the soil and air temperature above freezing. However, the vegetation was probably more sensitive to frost (Beerling et al., 2002) than under the lower $\mathrm{CO}_{2}$ concentrations of the present day. Therefore light in particular, coupled with temperature (probably to a 
lesser extent if ambient temperatures remained high enough during the growing season), may have been the limiting factor causing growth cessation. Growth rates (including radial growth) of trees were also probably enhanced due to the elevated atmospheric $\mathrm{CO}_{2}$ concentration (e.g. Norby et al., 1999; Osborne and Beerling, 2002). This renders the use of palaeoclimatic determination from the growth rings of fossil woods, without considering plant sensitivity to levels of atmospheric $\mathrm{CO}_{2}$, problematical especially in relation to estimates of warm month mean temperature (Osborne and Beerling, 2002) and mean annual sensitivity.

The question of whether the plants exhibited an evergreen or deciduous habit in polar ecosystems has been a focus of discussion for decades. The evergreen habit would not have been detrimental during the dark winter month(s) if extreme cold had prevailed as metabolic processes are minimal. In early spring evergreenness would have been advantageous because little energy would be required to initiate photosynthesis (Spicer and Chapman, 1990). However the climate is known to have been warm and atmospheric $\mathrm{CO}_{2}$ high so winter respiration rates may have been high enough to deplete the stored metabolites especially in the juvenile growth stages (Spicer and Chapman, 1990). The overriding conjecture has favoured a deciduous habit since carbon could be conserved as respiration is avoided during the long winter months (e.g. Spicer and Chapman, 1990). Recent modelling experiments (Osborne and Beerling, 2003; Royer et al., 2003; Osborne et al., 2004) on "living fossils" show that such conclusions can be refuted since the carbon cost of annually shedding leaves in deciduous trees greatly exceeds the cost of respiration in an evergreen canopy. Therefore attention needs to be paid to the morphology and anatomy (e.g. Falcon-Lang, 2000) exhibited by the fossils to determine whether the plants were evergreen or deciduous. This approach was adopted by FalconLang and Cantrill (2001) to determine the habit of late Albian Antarctic conifers. Based on five independent techniques they concluded that the canopy forming vegetation was predominantly evergreen. Araucarians and podocarps, which dominated the vegetation, held on to their leaves for at least 5-13 years whereas some of the rarer taxodiaceous conifers were evergreen but with much shorter leaf retention times. Based on other morphological evidence, Cantrill and Nichols (1996) concluded that other ?taxodiaceous conifers, ginkgos and taeniopterids were all deciduous along with the fern and angiosperm components of the understorey.

Angiosperm woods lack any evidence for leaf retention. Less than five specimens in total (including those specimens considered too small for palaeoclimate analysis) showed evidence of leaf traces and only one had a trace which possibly crossed more than one ring boundary. Therefore the angiosperm habit was probably not evergreen. The angiosperm material also show regular interruptions in growth, which would be expected if the plants were adapted to the polar environment by being deciduous. Growth interruptions are noted in the majority of angiosperm woods examined. The majority of specimens from the end of the Cretaceous through to the Middle Eocene exhibit distinct growth ring boundaries with little latewood suggesting a rapid transition from summer to winter. The period of global warmth during the Late Cretaceous (Coniacian-Campanian) is reflected in the absence of distinct growth rings in most specimens (also noted by Torres and Lemoigne, 1989; Chapman and Smellie, 1992). Interestingly although the angiosperm woods described from the Coniacian of Williams Point (Livingston Island) all appear diffuse porous with indistinct growth rings, the conifers from the same locality have wide, well-defined growth rings suggesting the climate was indeed seasonal, at least with regard to light intensity. The absence of distinct growth rings in angiosperm woods from the same flora remains problematical. Parish and Spicer (1988) suggest that the conifer ring characteristics seen in northern high latitude wood are a response to a rapid change in photoperiod at the end of the growing season through a biomechanical switch rather than as a result of a progressive limitation of resources such as water, temperature or light. This may suggest that the growth controls at the onset of dormancy in angiosperm wood were different when compared with conifer wood from the same locality (Chapman and Smellie, 1992). Considering the latitude and a cold month mean above $7.5{ }^{\circ} \mathrm{C}$ (Table 3) it seems likely that the controls for growth ring formation varied in different taxa such that conifers responded relatively quickly to a change in day length/light intensity when compared with the angiosperms which probably had a 
greater photosynthetic tolerance for lower light intensities/shorter day lengths.

The incidence of deferred optimum vessel diameter observed in a number of specimens studied, peaks in the Late Maastrichtian cool period suggesting that light and/or temperature were a controlling factor. The decrease in incidence throughout the Paleocene and into the Eocene not associated with proposed temperature fluctuations (Figs. 2 and 5) suggests that light exerted the overriding control.

Considering the palaeogeography of the Peninsula, seasonal hydrological variations would not have been great with precipitation distributed throughout the year and probably not limiting. In such environments ring porous woods would be expected to be relatively rare with semi-ring porous or diffuse porous woods being most common. Indeed diffuse porosity dominates during the Coniacian-Campanian warm period and the semi-ring porous condition is the usual state observed in woods dating from the Late Cretaceous through to the Middle Eocene suggesting relatively greater volumes of water per unit time were available early in the growing season.

False rings are totally absent from the specimens dating from the Coniacian-Campanian warm, wet period helping to confirm favourable conditions prevailing in the southern high latitudes during the mid Cretaceous. Conversely the greatest incidence of

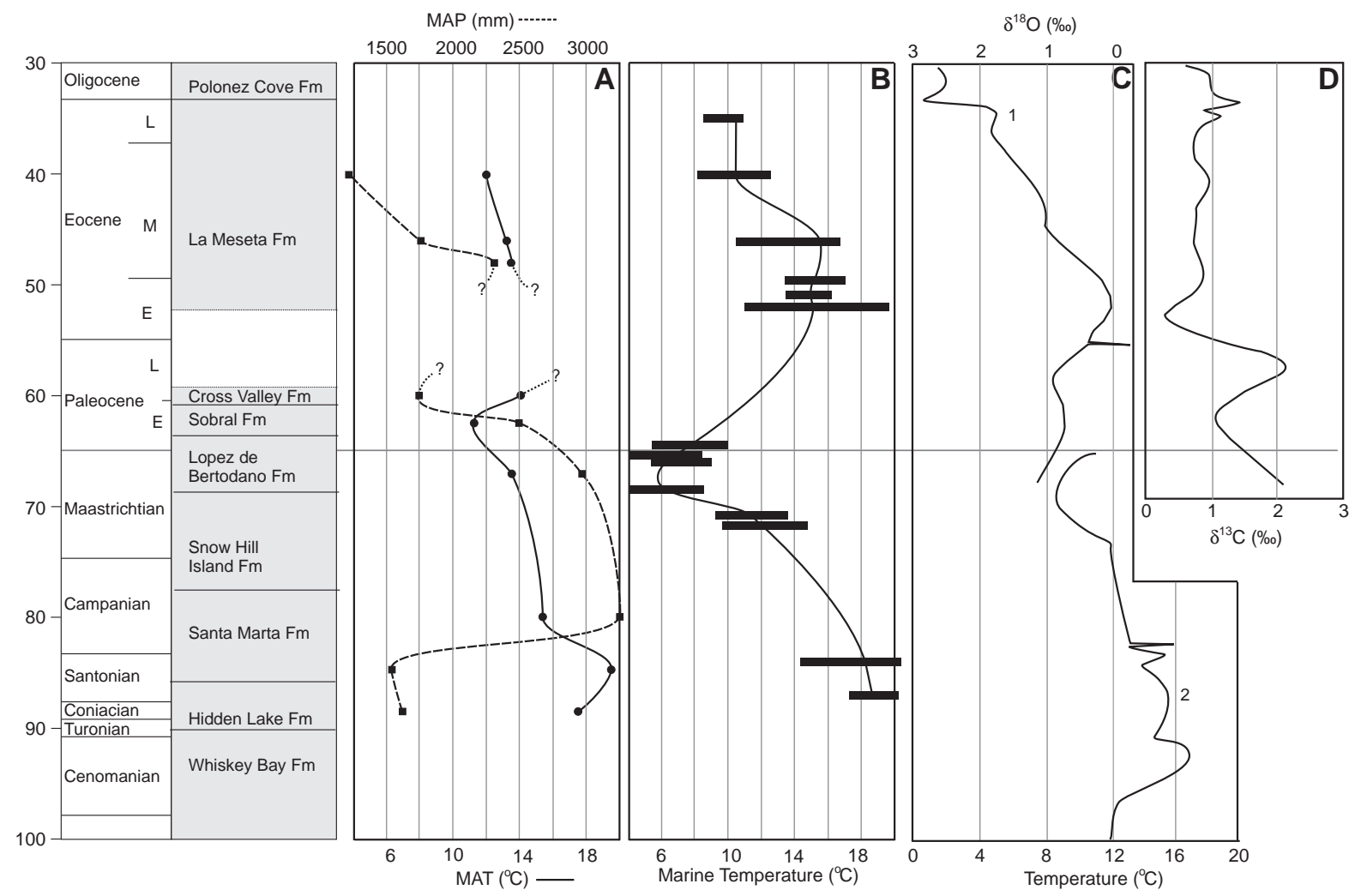

Fig. 5. Climate curves showing the change in terrestrial mean annual precipitation (MAP mm) and mean annual temperature (MAT ${ }^{\circ} \mathrm{C}$ ) from the Coniacian-Campanian to Middle Eocene for the Antarctic Peninsula region compared with deep sea marine temperature and global carbon isotope record. (A) MAP (dotted line) and MAT (solid line) based on the mean derived from all quantitative climate data given in Table 3. (B) Marine temperature curve calculated from data given in Barrera et al. (1987), Ditchfield et al. (1994), Pirrie and Marshall (1990) recalibrated to the recent stratigraphic interpretations and calibrations using high precision Sr ages (Crame et al., 2004). Ditchfield et al. (1994) calculated average temperatures for individual formations in this study we selected samples that now have good stratigraphic control and recalculated average temperatures from this data. (C) Deep sea oxygen isotope and temperature curve depicting ${ }^{1}$ global marine temperatures from Zachos et al. (2001) and ${ }^{2}$ marine temperatures for the southern high latitudes from Huber (1998). (D) Global carbon isotope curve from Zachos et al. (2001). 
false rings occurs in the woods from the Middle Eocene which is not surprising considering high latitude glaciation is thought to have begun at this time in East Antarctica (Dingle and Lavelle, 1998) causing climate deterioration in the West. The incidence of woods with frost rings is also relatively high (ca. 10\%) in the latest Early Paleocene and Early Eocene when annual precipitation levels are at their lowest suggesting unseasonally cold and/or dry conditions during the growing season.

\subsection{Late Cretaceous and Paleogene climate of the Antarctic Peninsula}

Attempts to understand the evolution of the Earth's climate system in deep time rely on a variety of proxy evidence. The most abundant data comes from fossil marine organisms that record surface and bottom water temperatures through stable isotope ratios. In contrast fossil floras provide information about atmospheric and terrestrial climatic conditions. The large heat capacity of the ocean compared with the atmosphere means that marine proxies are often seen as a measure of global climate when in reality they are a measure of oceanic conditions. A cursory examination of the present Earth reveals considerable contrast between oceanic conditions and neighbouring terrestrial environments. Cool water currents such as the Benguela along the west coast of Africa contrast markedly with the hot, arid desert environments of the adjacent land (e.g. Namibia) such that the juxtaposition of similar currents in the geological record would manifest as quite different results in the terrestrial and marine proxy data. Therefore it is important to consider both marine and terrestrial data wherever possible to retrodict past atmospheric conditions. Moreover recent work has suggested that understanding regional patterns of change are probably just as important in determining global processes of climatic change on geological scales (Barrett, 2003).

\subsubsection{Marine temperature fluctuations in the Antarctic Peninsula}

In the Antarctic Peninsula region oxygen isotope analyses of Early Cretaceous marine macrofossils and foraminifera (Barrera et al., 1987; Pirrie and Marshall, 1990; Ditchfield et al., 1994; Dutton et al., 2002) provide information on marine water temperatures
(Fig. 5). The data coverage compared with other regions of the southern hemisphere is relatively sparse, but indicates relatively cool Aptian-Albian marine temperatures followed by a warming into the Coniacian-Early Campanian. The lack of data from the Cenomanian to Turonian is problematic as peak temperatures are seen in this interval elsewhere in southern high latitudes (Huber et al., 1995). However, late Albian to late Turonian strata of the Whisky Bay Fm (Riding and Crame, 2002) contain elements of a re-worked shallow-water marine fauna with probable Tethyan affinities. This includes a colonial coral, oysters and other thick-shelled bivalves (J.A. Crame, personal communication). These taxa are not seen in younger strata of the James Ross Basin and thus suggest much warmer conditions during this interval in the Antarctic.

Long term cooling began in the latest Coniacian or Early Santonian based on the oxygen isotope analyses of marine macrofossils and foraminifera from the James Ross Basin (Ditchfield et al., 1994; Fig. 5). This cooling accelerates into the Maastrichtian with a steep decrease from $11.8{ }^{\circ} \mathrm{C}$ to $4-8.5{ }^{\circ} \mathrm{C}$ between 71 $\mathrm{Ma}$ and $68.5 \mathrm{Ma}$ (Fig. 5). Temperatures recover slightly towards the end of the Cretaceous through into the earliest Paleocene. No data is available for the Late Paleocene and Early Eocene interval but by the late Early Eocene temperatures had warmed by around $7{ }^{\circ} \mathrm{C}$. Temperatures initially remained stable until the Middle Eocene after which they started to decline (Dutton et al., 2002; Fig. 5).

\subsubsection{Terrestrial climatic variation in the Antarctic Peninsula}

Palaeoclimatic studies of the terrestrial southern high latitude environment have traditionally focused on extrapolations of climates using nearest living relative approaches (e.g. Doktor et al., 1996; Birkenmajer and Zastawniak, 1989). More recent studies have made quantitative determinations using morphology and anatomy of plant assemblages (e.g. Hayes, 1999; Hunt, 2001; Hunt and Poole, 2003; Francis and Poole, 2002; Francis et al., 2003). Here we attempt to bring together the results of previous studies and compare them with the quantitative data derived from the largest dataset ever compiled from fossil plant material from the Antarctic Peninsula region. 
Comparisons between the various methods that have been utilised to determine terrestrial climates highlight some important differences. In general the NLR and CA approaches yielded broader ranges than the multivariate anatomical analysis (Fig. 2). This is probably due to problems associated with assigning fossil taxa to extant groups from Early Tertiary and Cretaceous sequences. For example, in our CA analysis certain pollen types could only be assigned at generic or higher level, which probably results in a wider climatic range and consequently lower contrast. Despite the differences between the two approaches the pattern in MAT is broadly similar (Fig. 2). Peak temperatures were experienced in the Coniacian to Campanian interval and declined into the Maastrichtian with maximum cooling in the early Paleocene and a relatively cool middle Eocene.

Mean annual precipitation shows greater variation and the two approaches result in different shifts through this time interval. Physiognomic quantitative analysis shows wide variation in absolute levels between the different methods which is difficult to explain. The same result is also seen in the Middle Eocene (Fig. 2). This discrepancy not too surprising since many studies have noted the unreliable nature of MAP estimates using techniques such as CLAMP. Despite this high moisture levels are inferred from both approaches in the late Cretaceous whereas the Paleocene is characterised by drier conditions before becoming wetter again in the middle Eocene (Fig. 2). Mean annual precipitation shows greater variation and the two approaches result in different shifts through this time interval. As shown on Fig. 2, the curve derived from wood physiognomy shows major fluctuations with precipitation rates highest in the late Cretaceous (almost $6000 \mathrm{~mm}$ ) decreasing to ca. 2500 in the middle Eocene. CA and CLAMP, in contrast, consistently result in much lower MAP rates ranging about between 500 and $2500 \mathrm{~mm}$. In addition, the CA curve shows little variation in MAP within the timeinterval regarded. The reasons for the observed discrepancies are still unclear. Despite this, higher moisture levels are inferred from both approaches in the late Cretaceous whereas the Paleocene is characterised by drier conditions before becoming wetter again in the middle Eocene (Fig. 2).

Other studies in the Antarctic Peninsula region have attempted to determine terrestrial climatic con- ditions based on geological proxy evidence such as chemical alteration indices (Dingle and Lavelle, 1998, 2000). Although our data points are sparser than those in the study of Dingle and Lavelle (2000) the results have yielded similar patterns. Dingle and Lavelle (2000) suggested that the Early Paleocene was a period of cool to cold conditions with seasonal rainfall and was followed by warmer wetter conditions in the late Early Paleocene. Our data for rainfall shows a similar pattern with a decline in rainfall during this interval (Figs. 2 and 5) and more seasonal in nature (Table 3). A similar rainfall pattern was also suggested for the Santonian (Dingle and Lavelle, 2000) and this is consistent with our CA data.

\subsubsection{Comparison with global pattern of climate change}

The fragmentation of Gondwana through the Cretaceous and Paleogene had a profound effect on the Earth's oceanic and atmospheric circulation system. This interval has some of its most dramatic fluctuations in climate with maximal greenhouse conditions in the mid-Cretaceous culminating the warming trend that began in the Late Permian. Longterm cooling through the Late Cretaceous and Cenozoic is overprinted by warming intervals such as the early Paleogene and some extremely shortlived warm intervals, such as the Paleocene/Eocene Thermal Maximum (PETM, $\sim 55 \mathrm{Ma}$; Speijer and Wagner, 2002). Much of the information about these events is derived from high resolution deep sea oxygen and carbon isotope records (Zachos et al., 2001; Fig. 5).

The isolation of the Antarctic leading to widespread glaciation of the continent should have markedly changed global latitudinal temperature gradients. Cooling of the surface waters began in the late Early Campanian and continued through to the end of the Maastrichtian (Huber et al., 1995; Abreu et al., 1998). Global curves also show a cooling trend in the Late Maastrichtian (Huber, 1998). This trend is seen in the Antarctic Peninsula marine temperature record (Fig. 5) and the terrestrial proxy data although the cooling seems to be more rapid and pronounced in the marine realm. A steep decline in temperature is seen in the marine proxies during the Late Maastrichtian (Huber, 1992, 1998; Dingle and Lavelle, 2000; Fig. 5) and in the terrestrial realm this decline continues into the 
Early Paleocene. Dingle and Lavelle (2000) suggested that this trend may be related to the creation of a cold current on the west coast of Antarctica perhaps bought about by the separation of New Zealand and Lord Howe Rise from Australia leading to a cooler more polar circulation route. The lag between the marine and terrestrial record, along with the greater depth of cooling experienced in the marine realm supports this hypothesis with later but less intense cooling in the terrestrial record being a consequence of such a developing current. Cooler conditions as a result of such a change would also lead to lower rainfall as evidenced by the MAP curve (Fig. 5).

Despite the absence of Late Paleocene and Early Eocene strata in the Antarctic Peninsula, a comparison with the global temperature curve (Zachos et al., 2001) reveals certain similarities. A decline in marine temperatures is seen from the Early Eocene thermal optimum through to the Oligocene. This period of temperature decline does not appear to be coupled to the carbon cycle as the global carbon curve during this period is relatively flat (Fig. 5). The global curve has a distinct early Middle Eocene 'shoulder' before declining again to the Eocene-Oligocene boundary. One feature of the Antarctic marine data is the relative steepness of this curve compared with the global record. This suggests faster cooling between the early Middle Eocene and Oligocene boundary and greater isolation of the southern landmass and the development of steeper pole to equator temperature gradients. Limited sample points in the terrestrial realm also suggest a steeper rate of change during this interval. The fact that globally temperatures decline from the Early Eocene thermal peak apparently unlinked to fluctuations in the carbon cycle suggests carbon dioxide was not forcing climate during this period in Earth history and that some other process was responsible for long-term trends. Although circumstantial, it appears that the high latitude regions cooled more rapidly probably in response to plate reorganization and the creation of the southern ocean.

\section{Conclusions}

Remains of vegetation that once grew at high southern latitudes is represented by the abundant fossil wood that occurs in Cretaceous and Paleogene strata of the Antarctic Peninsula. The wood anatomy and the taxonomic makeup of the floras provide proxies for climate that prevailed at this time. However evolutionary processes associated with the physiological responses of plants to their environment manifesting themselves in wood characteristics may confound interpretations especially during the Cretaceous.

High ambient levels of atmospheric $\mathrm{CO}_{2}$ coupled with the proximity of the vegetated volcanic arc to the Southern Ocean during the Late Cretaceous to Middle Eocene suggest a prevailing maritime climate moderating temperature extremes and distributing precipitation throughout the year. Moreover the prevailing westerly windstream coupled with the mountainous terrain resulted in orographic rainfall. This is evidenced by negative values for the dry month mean estimates from the multivariate anatomical analyses, the presence of fungi in the majority of wood specimens, and the overriding diffuse porous and semiring porous condition exhibited by the angiosperm woods.

Seasonal winter darkness (and probable leaf fall in deciduous taxa) rather than precipitation deficit and/ or cold winter temperatures was the primary cause for growth cessation resulting in the high incidence of distinct growth rings in angiosperm woods. A similar scenario was probably experienced by the conifers, yet in the Paleogene wood with pronounced late wood zone of thickened cells suggests that this response was less marked. The presence of woods with deferred optimum vessel diameters from the Late Maastrichtian to Middle Eocene may also attest to this. The (surprising) dominance of angiosperm woods with indistinct growth rings and diffuse porosity in the Coniacian-Campanian is probably explained by wood physiology still evolving to adapt to seasonal environments.

A period of peak terrestrial warmth during the Coniacian-Early Campanian is supported by MAT estimates of up to $19{ }^{\circ} \mathrm{C}$ from leaf physiognomy (similar to that of Harare, Zimbabwe today) and up to $21{ }^{\circ} \mathrm{C}$ calculated by the CA. These high temperatures were associated with high levels of annual precipitation (Table 3, Figs. 3 and 5). However, peak warmth may have occurred earlier but cannot be detected due to a lack of Cenomanian to Turonian floras. 
The Late Cretaceous-Early Paleocene cooling phase is supported by wood physiognomy with temperatures possibly dropping to as low as ca. 3.5 ${ }^{\circ} \mathrm{C}$ (Table 3, Figs. 2 and 4) although CA suggests MAT dropped by ca. $5{ }^{\circ} \mathrm{C}$, from about $17.5^{\circ} \mathrm{C}$ in the Maastrichtian to ca. $12.5^{\circ} \mathrm{C}$ in the earliest Palaeocene. WMMT also dropped by almost $7.5^{\circ} \mathrm{C}$ from about 25 ${ }^{\circ} \mathrm{C}$ to $17.5{ }^{\circ} \mathrm{C}$ over this time-interval. MAT estimates for the Late Maastrichtian varies between $3.4{ }^{\circ} \mathrm{C}$ and $14{ }^{\circ} \mathrm{C}$ although more evidence indicates temperatures towards the upper end of this range (Table 3, Fig. 2). For the Early Paleocene temperatures are estimated to have gone up to ca. $12-13{ }^{\circ} \mathrm{C}$. Wood physiognomy suggests annual precipitation remained high with levels peaking in the Maastrichtian.

The distinct warming phase climaxing at the Late Paleocene-Early Eocene is observed with MAT estimates having risen to ca. $12{ }^{\circ} \mathrm{C}$ by the latest Early Paleocene. This compares well with estimates of ca. $13.5^{\circ} \mathrm{C}$ from leaf fossils of the same flora (Francis et al., 2003) and $14.6{ }^{\circ} \mathrm{C}$ from CA (Table 3; Fig. 2). In addition, significantly higher WMMT is calculated for this time-period (CA). Wood anatomical data estimates annual precipitation to have halved relative to the preceding Early Paleocene which may account for the relatively high incidence of false rings observed in the angiosperm woods at this time. The extent of this warming, drying period at southern high latitudes on land is not determinable as Late Paleocene and Early Eocene sediments are missing from the northern Peninsula region of Antarctica.

Climate deteriorated through the late Early and Middle Eocene with temperatures dropping to ca. $9{ }^{\circ} \mathrm{C}$ by the Middle Eocene which compares well with estimates ca. $8{ }^{\circ} \mathrm{C}$ derived from leaf analysis of the same flora. Moreover the CA records a decreasing temperature trend in WMMT by almost $6{ }^{\circ} \mathrm{C}$. The incidence of growth interruptions in angiosperm woods is highest in the Middle Eocene supporting the hypothesis of less favourable growing conditions at this time. According to multivariate analyses precipitation levels were once again rising. There is no immediate change from semi-ring to ring porous condition noted in the angiosperm woods at this time suggesting that seasonality had not greatly intensified. This would support the hypothesis for environmental dynamics rather than climatic change (Poole et al., 2001) controlling shifts in the vegetation seen this time.

\section{Acknowledgements}

We are indebted to BAS for the loan of fossil material and the opportunity for IP and DJC to undertake fieldwork in Antarctica. We thank Professor A. Gadzicki for loan of Antarctic material from the Polish Academy of Science, Mike Tabecki (BAS), Otto Stiekima (Utrecht University) and staff at Leeds University for sectioning the fossil material. This work was made possible by funding from NWO (grant number ALW/809.32.004) and through the HIGH LAT programme (HPRI-CT-2001-00125) awarded to IP which was made available by the European Community-Access to Research Infrastructure action of the Improving Human Potential Programme. The authors thank Dr. J. Chapman and an anonymous reviewer for comments on an earlier draft which have improved the manuscript.

\section{References}

Abreu, V.S., Hardenbol, J., Haddad, J., Haddad, G.A., Baum, G.R., Droxler, A.W., Vail, P.R., 1998. Oxygen isotope synthesis: a Cretaceous ice-house? In: de Graciansky, P.C., et al., (Eds.), Mesozoic and Cenzoic Sequence Stratigraphy of European Basins, Special Publication-Society for Sedimentary Geology $60,75-80$.

Askin, R.A., 1989. Endemism and heterochroneity in the Late Cretaceous (Campanian) to Paleocene palynofloras of Seymour Island, Antarctica: implications for origins, dispersal and palaeoclimates of southern floras. In: Crame, J.A. (Ed.), Origins and Evolution of the Antarctic Biota, Geological Society Special Publication 47, 217-226.

Askin, R.A., 1992. Late Cretaceous-Early Tertiary Antarctic outcrop evidence for past vegetation and climates. Antarctic Research Series 56, 61-73.

Askin, R.A., 1997. Eocene-?earliest Oligocene terrestrial palynology of Seymour Island. In: Ricci, C.A. (Ed.), The Antarctic Region: Geological Evolution and Processes. Terra Antarctica Publication, Siena, pp. 993-996.

Barrera, E., Huber, B.T., Savin, S.M., Webb, P.-N., 1987. Antarctic marine temperatures: Late Campanian through Early Paleocene. Paleoceanography 2, 21-47.

Barrett, P.J., 2003. Palaeoclimatology: cooling a continent. Nature 421, 2213-2223.

Beerling, D.J., Terry, A.C., Hopwood, C., Osborne, C.P., 2002. Feeling the cold: atmospheric $\mathrm{CO}_{2}$ enrichment and the frost sensitivity of terrestrial plant foliage. Palaeogeography, Palaeoclimatology, Palaeoecology 182, 3-13.

Birkenmajer, K., Zastawniak, E., 1989. Late Cretaceous-Early Tertiary floras of King George Island, West Antarctica: their stratigraphic distribution and palaeoclimatic signifi- 
cance. In: Crame, J.A. (Ed.), Origins and Evolution of the Antarctic Biota, Geological Society Special Publication 47, 227-240.

Cantrill, D.J., 2000. A petrified cycad trunk from the Late Cretaceous of the Larsen Basin, Antarctica. Alcheringa 24, 307-318.

Cantrill, D.J., Nichols, G.J., 1996. Taxonomy and palaeoecology of Lower Cretaceous angiosperm leaves from Alexander Island, Antarctica. Review of Palaeobotany and Palynology 92, 1-28.

Cantrill, D.J., Poole, I., 2002. Cretaceous patterns of floristic change in the Antarctic Peninsula. In: Crame, J.A., Owen, A.W. (Eds.), Palaeobiology and Biodiversity Change: A Comparison of the Ordovician and Mesozoic-Cenozoic Radiations, Special Publication-Geological Society of London 194, 141-152.

Cantrill, D.J., Poole, I., 2004. Taxonomic turnover and abundance in Cretaceous to Tertiary wood floras of Antarctica: implications for changes in forest ecology. Palaeogeography, Palaeoclimatology, Palaeoecology 215, 205-219.

Carlquist, S., 1977. Ecological factors in wood evolution: a floristic approach. American Journal of Botany 64, 887-896.

Carlquist, S., 2001. Comparative Wood Anatomy Systematic Ecological and Evolutionary Aspect of Dicotyledon Wood, 2nd edition. Springer Verlag, Berlin.

Chapman, J.L., 1994. Distinguishing internal developmental characteristics from external palaeoenvironmental effects in fossil wood. Review of Palaeobotany and Palynology 81, 19-32.

Chapman, J.L., Smellie, J.L., 1992. Cretaceous fossil wood and palynomorphs from Williams Point, Livingston Island, Antarctic Peninsula. Review of Palaeobotany and Palynology 74, $163-192$.

Crame, J.A., Francis, J.E., Cantrill, D.J., Pirrie, D., 2004. Maastrichtian stratigraphy of Antarctica. Cretaceous Research 25, 411-423.

DeConto, R.M., Pollard, D., 2003. Rapid Cenozoic glaciation of Antarctica induced by declining atmospheric $\mathrm{CO}_{2}$. Nature 421, 245-249.

Dettmann, M.E., 1989. Antarctica: Cretaceous cradle of austral temperate rainforests? In: Crame, J.A. (Ed.), Origins and Evolution of the Antarctic Biota, Geological Society Special Publication 47, 89-105.

Dettmann, M.E., Jarzen, D.M., 1991. Pollen evidence for Late Cretaceous differentiation of Proteaceae in southern polar forests. Canadian Journal of Botany 69, 901-906.

Dettmann, M.E., Thomson, M.R.A., 1987. Cretaceous palynomorphs from the James Ross Island area, Antarctica-a pilot study. British Antarctic Survey Bulletin 77, 13-59.

Dingle, R.V., Lavelle, M., 1998. Late Cretaceous-Cenozoic climate variations of the northern Antarctic Peninsula: new geochemical evidence and review. Palaeogeography, Palaeoclimatology, Palaeoecology 141, 215-232.

Dingle, R.V., Lavelle, M., 2000. Antarctic Peninsula Late Cretaceous-Early Cenozoic palaeoenvironments and Gondwana palaeogeographies. Journal of African Earth Sciences 31, 91-105.

Ditchfield, P.W., Marshall, J.D., Pirrie, D., 1994. High latitude palaeotemperature variation: new data from the Tithonian to
Eocene of James Ross Island, Antarctica. Palaeogeography, Palaeoclimatology, Palaeoecology 107, 79-101.

Doktor, M., Gazdzicki, A., Jerezmanska, A., Porebski, J., Zastawniak, E., 1996. A plant and fish assemblage from the Eocene La Meseta Formation of Seymour Island (Antarctic Peninsula) and its environmental implications. Palaeontologica Polonica 55, $127-146$.

Dutton, A.L., Lohmann, K.C., Zinsmeister, W.J., 2002. Stable isotope and minor element proxies for Eocene climate of Seymour Island, Antarctica. Paleoceanography 17, 1029.

Falcon-Lang, H.J., 2000. The relationship between leaf longevity and growth ring markedness in modern conifer woods and its implications for palaeoclimatic studies. Palaeogeography, Palaeoclimatology, Palaeoecology 160, 317-328.

Falcon-Lang, H.J., 2003. Do tree rings in fossil woods give a palaeoclimatic signal? International Association of Wood Anatomists Journal 24, 316.

Falcon-Lang, H.J., 2005. Intra-tree variability in wood anatomy, and its implications for fossil wood systematics and palaeoclimatic studies. Palaeontology 48, 171-183.

Falcon-Lang, H.J., in press. Global climate analysis of growth rings in woods and its implications for deep time paleoclimate studies. Paleobiology 31.

Falcon-Lang, H.J., Cantrill, D.J., 2001. Leaf phenology of some mid-Cretaceous polar forests, Alexander Island, Antarctica. Geological Magazine 138, 39-52.

Francis, J.E., Poole, I., 2002. Cretaceous and Tertiary climates of Antarctica: evidence from fossil wood. Palaeogeography, Palaeoclimatology, Palaeoecology 182, 47-64.

Francis, J.E., Tosolini, A.M., Cantrill, D.J., 2003. Biodiversity and acclimate change in Antarctic Paleogene floras. In: Fütterer, D.K. (Ed.), 9th International Symposium on Antarctic Earth Sciences, Terra Nostra, vol. 2003/4, p. 107.

Greenhalgh, J., 2002. A palynological investigation into palaeoenvironmental changes in the early Cenozoic sediments of Seymour Island, Antarctica, $\mathrm{PhD}$ thesis University College of London.

Haas, H., Rowe, N.P., 1999. Thin sections and wafering. In: Jones, T.P., Rowe, N.P. (Eds.), Fossil Plants and Spores: Modern Techniques. Geological Society of London, pp. 76-81.

Hayes, P.A., 1999. Cretaceous angiosperm floras from Antarctica. $\mathrm{PhD}$ thesis, University of Leeds.

Huber, B.T., 1992. Upper Cretaceous planktonic foraminiferal biozonation for the Austral Realm. Marine Micropaleontology 20, $107-1128$.

Huber, B.T., 1998. Tropical paradise at Cretaceous poles? Science 282, 2199-2200.

Huber, B.T., Hodell, D.A., Hamilton, C.P., 1995. Middle-Late Cretaceous climate of the southern high latitudes: stable isotopic evidence for minimum equator-to-pole thermal gradients. Geological Society of America Bulletin 107, 1164-1191.

Hunt, R.H., 2001. Biodiversity and palaeoecology of Tertiary fossil floras in Antarctica. PhD thesis, University of Leeds.

Hunt, R.J., Poole, I., 2003. Revising Palaeogene West Antarctic climate and vegetation history in light of new data from King George Island. In: Wing, S.L., Gingerich, P.D., Schmitz, B., Thomas, E. (Eds.), Causes and Consequences of Globally Warm 
Climates in the Early Paleogene, Special Paper-Geological Society of America 369, 395-412.

Jefferson, T.H., 1982. Fossil forests from the Lower Cretaceous of Alexander Island, Antarctica. Palaeontology 25, $681-708$.

Kennett, J.P., 1977. Cenozoic evolution of Antarctic glaciation, the circum-Antarctic Ocean and their impact on global paleoceanography. Journal of Geophysical Research 82, 3843-3860.

Kershaw, A.P., Nix, H.A., 1988. Quantitative palaeoclimatic estimates from pollen data using bioclimatic profiles of extant taxa. Journal of Biogeography 15, 589-602.

Lawver, L.A., Gahagan, L.M., Coffin, M.E., 1992. The development of palaeoseaways around Antarctica. Antarctic Research Series $56,7-30$.

Liang, M.-M., Bruch, A., Collinson, M.E., Mosbrugger, V., Li, C.-S., Sun, Q.-G., Hilton, J., 2003. Testing the climatic estimates from different palaeobotanical methods: an example from the Middle Miocene Shanwang flora of China. Palaeogeography, Palaeoclimatology, Palaeoecology 198, 279-301.

Mosbrugger, V., 1999. The nearest living relative method. In: Jones, T.P., Rowe, N.P. (Eds.), Fossil Plants and Spores Modern Techniques. The Geological Society, London, pp. 261-265.

Mosbrugger, V., Utescher, T., 1997. The coexistence approachmethod for quantitative reconstructions of Tertiary terrestrial palaeoclimate data using plant fossils. Palaeogeography, Palaeoclimatology, Palaeoecology 134, 61-86.

Norby, R.J., Wullschleger, S.D., Gunderson, C.A., Johnson, D.W., Ceulemans, R., 1999. Tree responses to rising $\mathrm{CO}_{2}$ in field experiments: implications for the future forest. Plant, Cell and Environment 22, 683-714.

Ohga, N., 1987. The plant ecology of the cloud forests of the eastern and western slopes of the Andes I. Microclimatic conditions of the forests of Bolivia and Chile. In: Nishida, M. (Ed.), Contributions to the Botany of the Andes II. Academia Scientific Book Inc., Tokyo, pp. 12-22.

Osborne, C.P., Beerling, D.J., 2002. Sensitivity of tree growth to a high $\mathrm{CO}_{2}$ environment: consequences for interpreting the characteristics of fossil wood from ancient 'greenhouse' worlds. Palaeogeography, Palaeoclimatology, Palaeoecology $182,15-29$.

Osborne, C.P., Beerling, D.J., 2003. The penalty of a long, hot summer. Photosynthetic acclimation to high $\mathrm{CO}_{2}$ and continuous light in "living fossil" conifers. Plant Physiology 133, $803-812$.

Osborne, C.P., Royer, D.L., Beerling, D.J., 2004. Adaptive role of leaf habit in extinct polar forests. International Forestry Review 6, 181-186.

Parish, J.T, Spicer, R.A., 1988. Middle Cretaceous wood from the Nanushuk Group, central North Slope, Alaska. Palaeontology $31,19-34$.

Partridge, A.D., 2002. Quantitative palynological analysis of outcrop samples from the López de Bertadano Formation James Ross Basin, northern Antarctic Peninsula. Biostrata Report 2002/25, pp. 1-52.

Pearson, P.N., Palmer, M.R., 2000. Atmospheric carbon dioxide concentrations over the past 6-million years. Nature 406, $695-699$.
Pirrie, D., Marshall, J.D., 1990. High paleolatitude Late Cretaceous paleotemperatures. New data from James Ross Island, Antarctica. Geology 18, 31-34.

Poole, I., Cantrill, D.J., 2001. Fossil woods from Williams Point Beds; Livingston Island, Antarctica: a Late Cretaceous southern high latitude flora. Palaeontology 44, 1081-1112.

Poole, I., van Bergen, P.F., in press. Physiognomic and chemical characters in wood as palaeoclimate proxies. International Journal of Plant Ecology.

Poole, I., Richter, H., Francis, J.E., 2000. Gondwanan origins for Sassafras (Lauraceae)? Evidence from Late Cretaceous fossil wood of Antarctica. International Association of Wood Anatomists Journal 21, 463-475.

Poole, I., Hunt, R.J., Cantrill, D.J., 2001. A fossil wood flora from King George Island: ecological implications for an Antarctic Eocene vegetation. Annals of Botany 88, 33-54.

Poole, I., Mennega, A.M.W., Cantrill, D.J., 2003. Valdivian ecosystems in the late Cretaceous and Early Tertiary of Antarctica as evidenced from fossil wood. Review of Palaeobotany and Palynology 124, 9-27.

Poole, I., van Bergen, P.F., Kool, J., Schouten, S., Cantrill, D.J., 2004. Molecular isotopic heterogeneity of fossil organic matter: implications for $\delta^{13} \mathrm{C}_{\text {biomass }}$ and $\delta^{13} \mathrm{C}_{\text {palaeoatmosphere proxies. }}$ Organic Geochemistry 35, 1261-1274.

Pross, J., Bruch, A.A., Kvacek, Z., 1998. Paläoklima-Rekonstruktionen für den Mittleren Rupelton (Unter-Oligozän) des Mainzer Beckens auf der Basis mikro-und makro-botanischer Befunde. Mainzer Geowissenschaftliche Mitteilungen 27, 79-92.

Riding, J.B., Crame, J.A., 2002. Aptian to Coniacian (Early-Late Cretaceous) palynostratigraphy of the Gustav Group, James Ross Basin, Antarctica. Cretaceous Research 23, 739-760.

Royer, D.L., Osborne, C.P., Beerling, D.J., 2002. High $\mathrm{CO}_{2}$ increases the freezing sensitivity of plants: implications for palaeoclimatic reconstructions from fossil floras. Geology 30, 963-966.

Royer, D.L., Osborne, C.P., Beerling, D.J., 2003. Carbon loss by deciduous trees in $\mathrm{CO}_{2}$-rich ancient polar environment. Nature $424,60-62$.

Speijer, R.P., Wagner, T., 2002. Sea-level changes and black shales associated with the late Paleocene thermal maximum (LPTM); organic-geochemical and micropaleontologic evidence from the southern Tethyan margin (Egypt-Israel). In: Koeberl, C., MacLeod, K.G. (Eds.), Catastrophic Events and Mass Extinctions: Impacts and Beyond, GSA Special Paper 356, $533-549$.

Spicer, R.A., Chapman, J., 1990. Climate change and the evolution of high-latitude terrestrial vegetaion and floras. Trends in Ecology and Evolution 5, 279-284.

Torres, T., 1990. Etude paléobotanique du Tertiaire des Iles Roi Georges et Seymour Antarctique. PhD thesis, l'Université Claude Bernard, Lyon.

Torres, T., Lemoigne, Y., 1989. Hallazagos de maderas fósiles de angiospermas y gimnospermas del Cretácico Superior en punta Williams, isla Livingston, islas Shetland del Sur, Antárctica. Instituto Antartico Chileno. Serie Cientifica 39, 9-29.

Torres, T., Marenssi, S., Santillana, S., 1994. Fossil wood of La Meseta Formation, Seymour Island, Antarctica. Serie Cientifica - Instituto Antartico Chileno 44, 17-38. 
Uhl, D., Mosbrugger, V., Bruch, A., Utescher, T., 2003. Reconstructing palaeotemperatures using leaf floras-case studies for a comparison of leaf margin analysis and the coexistence approach. Review of Palaeobotany and Palynology 126, 49-64.

Utescher, T., Mosbrugger, V., Ashraf, A.R., 2000. Terrestrial climate evolution in Northwest Germany over the last 25 million years. Palaios 15, 430-449.

Wheeler, E.A., Baas, P., 1991. A survey of the fossil record for dicotyledonous wood and its significance for evolutionary and ecological wood anatomy. International Association of Wood Anatomists Bulletin 12, 275-332.

Wiemann, M.C., Manchester, S.R., Dilcher, D.L., Hinojosa, L.F., Wheeler, E.A., 1998a. Estimation of temperature and precipitation from morphological characters of dicotyledonous leaves. American Journal of Botany 85, 1796-1802.

Wiemann, M.C., Wheeler, E.A., Manchester, S.R., Portier, K.M., 1998b. Dicotyledonous wood anatomical characters as predictors of climate. Palaeogeography, Palaeoclimatology, Palaeoecology $139,83-100$.

Wiemann, M.C., Manchester, S.R., Wheeler, E.A., 1999. Paleotemperature estimation from dicotyledonous wood anatomical characters. Palaios 14, 459-474.
Wiemann, M.C., Dilcher, D.L., Manchester, S.R., 2001. Estimation of mean annual temperature from leaf and wood physiognomy. Forest Science 47, 141-149.

Wilf, P., 1997. When are leaves good thermometers? A new case for leaf margin analyses. Paleobiology 23, 373-390.

Wolfe, J.A., 1971. Tertiary climate fluctuations and methods of analysis of Tertiary floras. Palaeogeography, Palaeoclimatology, Palaeoecology 9, 27-57.

Wolfe, J.A., 1979. Temperature parameters of humid to mesic forests of Eastern Asia and relation to forests of other regions of the Northern Hemisphere and Australasia. Geological Survey Professional Papers 1106, 1-37.

Wolfe, J.A., 1993. A method of obtaining climatic parameters from leaf assemblages. United States Geological Survey Bulletin 2040, 1-71.

Zachos, J.C., Pegani, M., Stone, L., Thomas, E., Billups, K., 2001. Trends, rhythms, and aberrations in global climates 65 Ma to present. Science 292, 293-686. 